Review

\title{
The Ascidian-Derived Metabolites with Antimicrobial Properties
}

\author{
Marcello Casertano $\left(\mathbb{D}\right.$, Marialuisa Menna * ${ }^{-1}$ and Concetta Imperatore ${ }^{(1)}$ \\ Department of Pharmacy, University of Naples “Federico II”, Via D. Montesano 49, 80131 Napoli, Italy; \\ marcello.casertano@unina.it (M.C.); cimperat@unina.it (C.I.) \\ * Correspondence: mlmenna@unina.it; Tel.: +39-081678518
}

Received: 30 June 2020; Accepted: 11 August 2020; Published: 13 August 2020

\begin{abstract}
Among the sub-phylum of Tunicate, ascidians represent the most abundant class of marine invertebrates, with 3000 species by heterogeneous habitat, that is, from shallow water to deep sea, already reported. The chemistry of these sessile filter-feeding organisms is an attractive reservoir of varied and peculiar bioactive compounds. Most secondary metabolites isolated from ascidians stand out for their potential as putative therapeutic agents in the treatment of several illnesses like microbial infections. In this review, we present and discuss the antibacterial activity shown by the main groups of ascidian-derived products, such as sulfur-containing compounds, meroterpenes, alkaloids, peptides, furanones, and their derivatives. Moreover, the direct evidence of a symbiotic association between marine ascidians and microorganisms shed light on the real producers of many extremely potent marine natural compounds. Hence, we also report the antibacterial potential, joined to antifungal and antiviral activity, of metabolites isolated from ascidian-associate microorganisms by culture-dependent methods.
\end{abstract}

Keywords: ascidian; antibacterial; antimicrobial; antiviral; marine natural products; ascidianassociated microorganisms

\section{Introduction}

Antimicrobial agents (including antibiotic, antiviral, antifungal, and antiprotozoal drugs) certainly are critical tools for the treatment of infectious diseases, and many feats of modern medicine and surgery also are determined by the availability of effective antibiotics. Unfortunately, many microorganisms have developed several and different mechanisms of drug-resistance, mainly owing to the misuse and overdose of antimicrobial drugs. Indeed, many marketed anti-infective drugs are losing their efficacy at a rapid pace, and antimicrobial resistance has emerged as one of the major problems that the public health has had to face in the 21st century [1,2]. It has been estimated that, by the year 2050, ten million people will die per year worldwide as a direct consequence of antimicrobial resistance [3]. Resistant infections are on the rise globally, and all countries are affected. In the United States, about 3 million people get an antibiotic-resistant infection each year, with more than 35,000 deaths. On the other hand, in Europe antibiotic resistant causes 33,000 deaths annually. As for children and neonates, they are disproportionately affected by antibiotic resistant infections, particularly in the poorest regions worldwide. For example, approximatively $30 \%$ of neonates affected by sepsis die as a result of the ineffectiveness of antibiotic treatment [2]. Thus, the need for novel antimicrobial drugs is truly great and, besides the search for vaccines as well as for novel diagnostic tools to understand the resistance mechanisms, considerable importance is given to find new chemical scaffolds for antibiotic development. However, where we can find new lead compounds with unprecedented activities?

Natural products, which are the result of the countless possible interactions among the millions of diverse terrestrial and marine species existing worldwide, are evolutionarily optimized as intrinsic 
drug-like molecules and play an increasingly crucial role in drug discovery owing to their great chemical diversity. The wide chemical space occupied by the secondary metabolites of living organisms and microorganisms is an authentic example of how combinatorial chemistry has been performed by nature for thousands of years, giving a real arsenal of drug lead candidates [4]. The marine environment covers $71 \%$ of the Earth's surface and comprises $50-80 \%$ of the total global biodiversity, which translates into an enormous chemical diversity [5]; every year, hundreds of novel compounds are isolated and identified, especially from marine invertebrates [6-17]. In fact, these species are sessile or slow moving and soft bodied; although they commonly host microorganisms, they lack the sophisticated adaptable immune systems seen in vertebrates. Nevertheless, they thrive and keep themselves free of infections, which means that they rely entirely on their innate immune system. It has been widely proven that, as a part of their effort for survival, marine invertebrates have developed biosynthetic pathways for production of a wealth of secondary metabolites to be used as chemical defense and communication. In this evolutionary process, their symbiotic association with microorganisms plays a key role [18].

Among the marine invertebrates, ascidians are the most closely related to humans; they constitute the biggest and most varied class of the sub-phylum Tunicata, comprising about 3000 described species [19]. Ascidians have been shown to be an exceptionally important source of natural products with biomedical and pharmaceutical applications, especially, but not exclusively in cancer [10,11,20-22]. Furthermore, ascidians harbour a great microbial community (including bacteria, actinobacteria, cyanobacteria, and fungi; Figure 1A), which represents an additional source of natural products, many of which are extremely potent and mainly cytotoxic and antimicrobial, but also antioxidant, anti-inflammatory, and many others (Figure 1B) [23]. Indeed, it has been proven that about $8 \%$ of the bioactive molecules isolated from ascidians derive from symbiotic microorganisms; recently, the development of culture-independent methods allowed to isolate and study the ascidian-associated microorganisms and their involvement in the synthesis of bioactive metabolites isolated from the invertebrates [24].

A

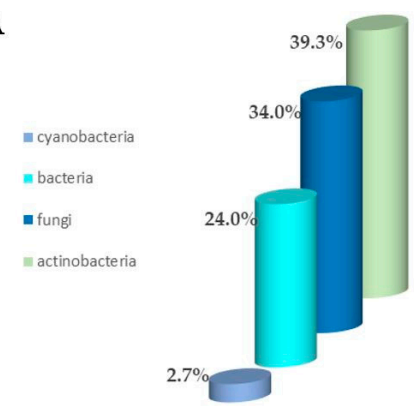

B

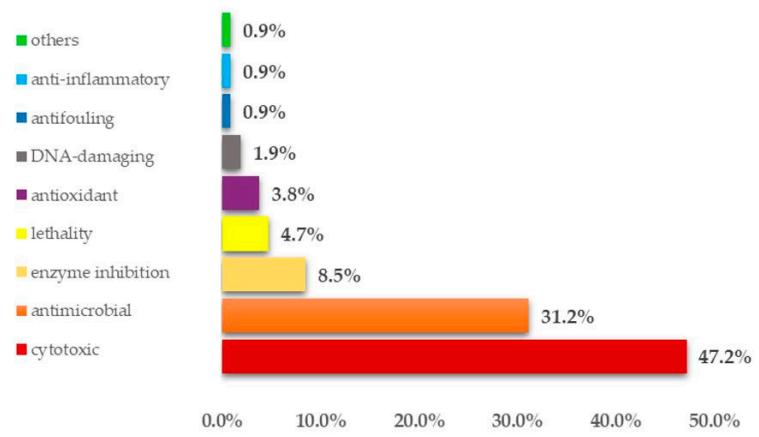

Figure 1. (A) Percentage distribution of microorganisms paired to ascidians from which marine metabolites derive; (B) bioactivities of secondary metabolites isolated from ascidian-associated microorganisms described as percentage distribution.

The aim of the present review is to focus the chemical diversity of the secondary metabolites with antibacterial activity (often joint to antiviral, antifungal, or antiprotozoal effects) isolated from marine ascidians through January 2020. This collection shows that, so far, more than 160 substances have been identified from marine ascidians with this activity, with different chemical structures and, therefore, most likely acting through different mechanisms. Their chemical and pharmacological properties are described herein; the molecules have been classified and grouped on the basis of some their common chemical features, in order to give a rational view of the high potential of ascidians as a source of new chemical scaffolds to be used as antimicrobial leads. Finally, a conspicuous section of the review has been devoted to the recent progress in the study of some ascidians-associated microorganisms and their role in the production of the bioactive metabolites. 


\section{Results and Discussion}

\subsection{Sulfur-Containing Metabolites: Polysulfides and Alkyl Sulfates}

Generally, natural products contain one or two heteroatoms like nitrogen and/or oxygen, sometimes more than two, whereas a sulfur atom is rarely found in metabolites of marine origin [25,26]. The ascidians belonging to the genus Lissoclinum (Didemnidae) are an exceptional source of unique chemical scaffolds, some of them endowed with antiviral activity as well as against mammalian cells $[27,28]$. Among these metabolites, several structurally intriguing antimicrobial polysulfides have been identified from Lissoclinum and Polycitor species, active against an array of pathogenic bacteria, fungi, and other infective agents [29-32]. The bioassay-guided chemical investigation of L. perforatum led to the isolation of lissoclinotoxins A (1) and B (2), (Figure 2) [29,30]. An extensive pharmacological characterization of these polysulfides [30] evidenced that compound $\mathbf{1}$ was active against Staphylococcus aureus, showing very low minimum inhibitory concentration (MIC) values $(0.08-0.15 \mu \mathrm{g} / \mathrm{mL})$, in the same range of those of cefatoxim. On the other hand, when compounds 1 and 2 were tested against Aeromonas salmonicida and Vibrio anguillarium by the inhibition zones assay, lissoclinotoxin B (2) was more potent that $\mathbf{1}$ against both bacteria, mainly against $A$. salmonicida with an $8 \mathrm{~mm}$ inhibition zone when tested at $5 \mu \mathrm{g}$ with respect to 1 , which showed only $40 \mathrm{~mm} / 30 \mu \mathrm{g}$ [28]. Compound 1 exhibited further antimicrobial properties; it showed moderate toxic effects against Trichosporon mentagrophytes and Candida albicans fungal strains, with MIC of 20 and $40 \mu \mathrm{g} / \mathrm{mL}$, respectively [30], and was also active against a resistant strain of Plasmodium isolated from infected erythrocytes. In this latter case, it exhibited a lower $\mathrm{IC}_{50}$ value $(296 \mathrm{nM})$ with respect to the commercially available antimalarials chloroquine and quinine ( $\mathrm{IC}_{50}$ values of 580 and 350, respectively).

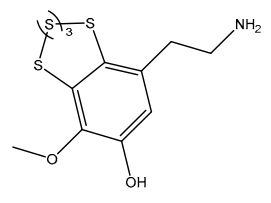

lissoclinotoxin A (1)

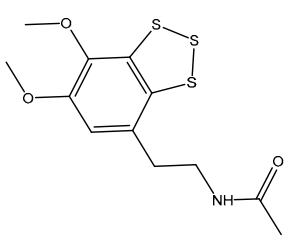

varacin $\mathrm{A}$ acetate (4)

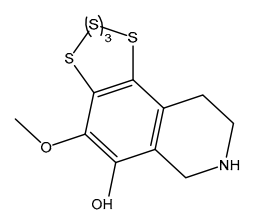

lissoclinotoxin B (2)

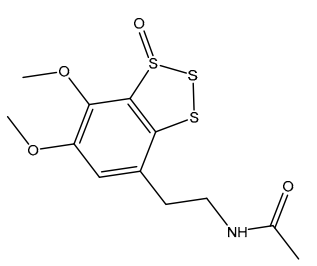

varacin B acetate (5)
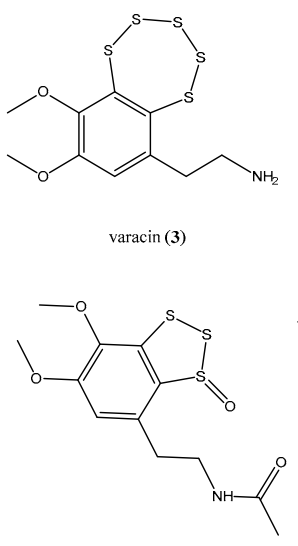

varacin C acetate (6)

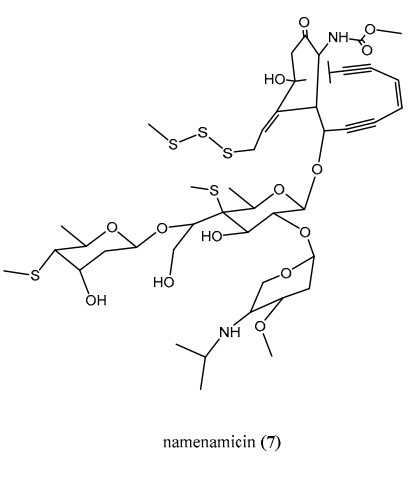

(1-2), varacins $(3-6)$,

Figure 2. Structures

In a first study, the antifungal properties of the benzopentathiepin varacin (3, Figure 2), isolated from $L$. vareau, were demonstrated against $C$. albicans, with a $14 \mathrm{~mm}$ zone of inhibition when tested at $2 \mu \mathrm{g}$ per disk [31]. However, it was strongly cytotoxic, being 100 times more potent than 5-fluorouracil with an $\mathrm{IC}_{90}$ of $0.05 \mu \mathrm{g} / \mathrm{mL}$ against human colon cancer HCT 116; its role in the damage of DNA was proven too [31]. The role played by ascidians-associated microorganisms in the synthesis of their secondary metabolites is sometimes suggested by the discovery of analogous and/or the same compounds in ascidians belonging to different genus and families as well as collected in completely different areas. This is the case of varacin (3), which was also recovered from the colonial ascidian Polycitor sp. [32] along with three further polysulfides, isolated as acetates (varacin A-C acetates, 4-6, Figure 2). Compounds 3-6 were subjected to antibacterial and antifungal assays; as varacin (3), the acetates 4-6 exhibited strong activity in vitro against $C$. albicans. In addition, both varacin (3) and 
the derivatives 4-6 were effective against the Gram-positive Bacillus subtilis, with 3 being 10 -fold more active than compounds 4-6.

Polysyncraton lithostrotum, an ascidian of Didemnidae family, was the source of namenamicin (7, Figure 2), a compound with an unusual "enediyne warhead" and an S-methyl group appended to a sugar moiety [33]. Compound 7 exhibited interesting antibiotic properties, being more potent than penicillin G against Enterococcus faecium, Klebsiella pneumoniae, C. albicans, Ustilago maydis, Saccharomyces cerevisiae, and Neurospora crassa, with MIC values of $0.03,0.06,0.25,0.004,0.06$, and $0.25 \mu \mathrm{g} / \mathrm{mL}$, respectively. However, as varacin, namenamicin exerted a strong cytotoxic effect in vitro [33].

Metabolites endowed with sulfated groups, although rather unusual, occur in marine invertebrates; nevertheless, in the last years, sulfated alkanes and alkenes are increasingly turning out to be common natural products of marine ascidians [34,35]. The chemical analysis of the ascidian Halocynthia roretzi allowed the identification of the antimicrobial alkyl sulfates 2,6-dimethylheptyl sulfate (8) such as racemate, (4Z, 7Z)-4,7-decadienyl sulfate (9), (4Z, 7E)-4,7-decadienyl sulfate (10), and (3Z, 6Z)-3,6,9-decatrienyl sulfate (11) (Figure 3) active against the Gram-negative marine bacterium $V$. alginolyticus and the fungus Mortierella ramaniana [36]. The activity was evaluated by paper disk method by administration of $0.2 \mathrm{mg}$ per disk of each compounds. Moreover, Fusetani and co-workers investigated the occurrence of these compounds in the ascidian tissues. Dissection of $H$. roretzi provided several ascidian tissues (i.e., hepatopancreas, gonad, tunic, body muscle, and hemolymph), which were separately analyzed. Alkyl sulfates 8-11 were found only in the hepatopancreas of the organism, underlining that these sulfates may be involved in some physiological processes of ascidian digestive system [36].

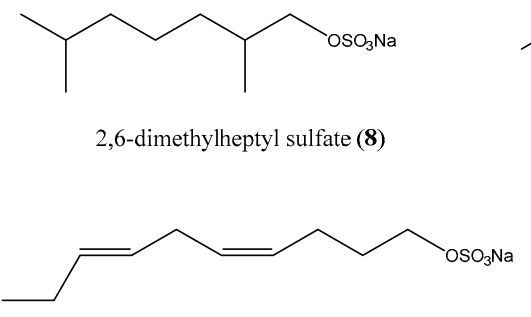

(4Z,7E)-4,7-decadienyl sulfate (10)

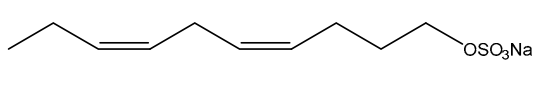

(4Z,7Z)-4,7-decadienyl sulfate (9)

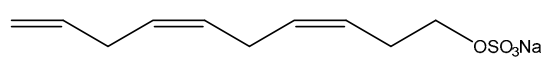

(3Z,6Z)-3,6,9-decatrienyl sulfate (11)

Figure 3. Structures of alkyl and alkenyl sulfates 8-11.

\subsection{Meroterpenes}

Molecules of mixed biosynthesis consisting of quinone/hydroquinone rings bonded to a prenyl portion are commonly called meroterpenes; they have a wide occurrence in nature and are considered "privileged scaffolds" in medicinal chemistry owing to their wide range of bioactivities, often owing to the quinone/hydroquinone moieties undergoing redox cycling [37-40]. This latter generates an oxidative burst accompanied by a huge and transient amount of reactive oxygen species (ROS), responsible for cellular damage. For this reason, both natural and synthetic prenylated quinones and hydroquinones found extensive application in the field of chemotherapy and cancer-preventive treatment [41-43]. A number of antimicrobial prenylated quinones from ascidians have been discovered too. Cordiachromene A (12) and epiconicol (13) are two geranylhydroquinone derivatives isolated from Synoicum castellatum, a species closely allied to the ascidians of genus Aplidium (Figure 4) [44]. In fact, naloogues quinoid compounds with a mixed shikimate-mevalonate biogenesis have been found in several Aplidium species. Conidione (14, Figure 4), with cytotoxic, anti-inflammatory, and even anti-HIV activity, has been isolated from samples of A. conicum [45], and all three compounds 12-14 have been recovered from $A$. densum, along with methoxyconidiol (15) and didehydroconicol (16, Figure 4) [38,46]. The antibacterial activity of compounds $\mathbf{1 2}-\mathbf{1 6}$ was quantitatively determined against the Gram-negative bacterium E. coli and the Gram-positive bacterium Micrococcus luteus. The tested compounds 12-16 did not show any activity against $E$. coli. On the other hand, epiconicol (13, MIC $=0.13 \mathrm{mmol})$, didehydroconicol $(\mathbf{1 6}, \mathrm{MIC}=0.52 \mathrm{mmol})$, and cordiachromene $\mathrm{A}(\mathbf{1 2}, \mathrm{MIC}=0.51 \mathrm{mmol})$ showed weak 
activity against $M$. luteus. Studies were conducted on the active meroterpenes $(\mathbf{1 2}, \mathbf{1 3}$, and $\mathbf{1 6})$ in order to distinguish for bacteriostatic or bactericidal effect. In the case of $\mathbf{1 2}$, as bacterial growth did not restart, an aliquot of the bacteria suspension treated with this compound was placed on a solid nutritive medium; compound 12 caused bacterial killing and could be considered as bactericidal [46,47]. Instead, $\mathbf{1 3}$ and $\mathbf{1 6}$ only inhibited the bacterial growth in the solid medium, thereby showing a bacteriostatic effect [46].

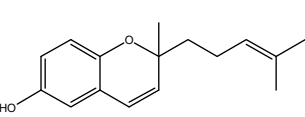

cordiachromene A (12)

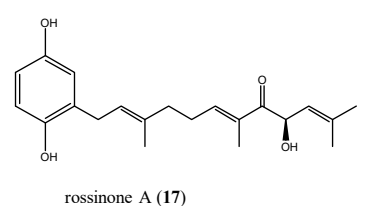

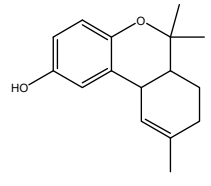

epiconicol (13)

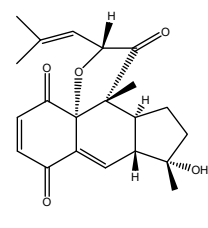

rossinone B (18)

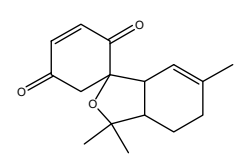

conidione (14)

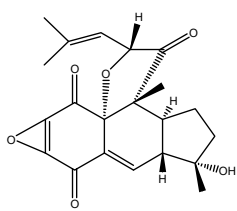

2,3- epoxy-rossinone B (19)

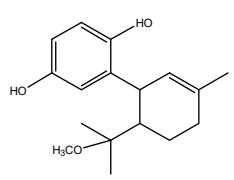

methoxyconidiol (15)

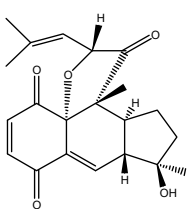

3-epi-rossinone B (20)

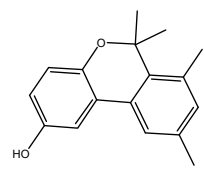

didehydroconicol (16)

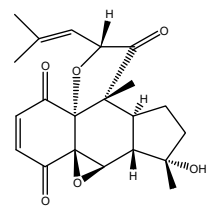

5,6-epoxy-rossinone B (21)

Figure 4. Structures of the geranylhydroquinone derivatives 12-16 and of rossinones (17-21).

The triprenylated hydroquinones, rossinones A and B (17 and 18, Figure 4), possessing a rare linear fused 6,6,5-ring core, were isolated during a campaign to collect colonial ascidians of genus Aplidium in Ross Sea [48]. Both compounds 17 and 18 exhibited antimicrobial activity against the bacterium B. subtilis and the fungi Trichophyton mentagrophytes (3-6 mm excess radius at $60 \mu \mathrm{g} / \mathrm{disk}$ ) and an antiviral effect ( $2 \mu \mathrm{g} /$ disk) toward DNA Herpes simplex virus 1 (HSV-1) and RNA Poliovirus-1 (PV-1). Moreover, only rossinone B (18) had antiproliferative activity inhibiting SH-SY5Y neuroblastoma $\left(\mathrm{IC}_{50}=1.6 \mu \mathrm{M}\right)$ and P388 murine leukaemia $\left(\mathrm{IC}_{50}=0.084 \mu \mathrm{M}\right)$ cell lines [48]. Rossinone B (18) was later re-isolated from Antarctic samples of $A$. fuegiense, together with several minor analogues, 2,3-epoxy-rossinone B (19), 3-epi-rossinone B (20), and 5,6-epoxy-rossinone B (21, Figure 4) [49,50]. This study revealed, through chemical analysis of the dissected parts of the organism separately, that these metabolites were concentrated in the colony inner part (viscera) and only a small amount of compound 18 was recovered in the external part (tunic) [49]. Generally, in the colonial ascidians, the defensive chemicals are concentrated in special cells in the outer tunic, while other intermediate products remain in the inner producing tissues [50]. This could explain the distribution observed for the rossinone compounds in A. fuegiense, where rossinone B could be the major and most active defensive metabolite, and thus present mainly in the inner tissues, but also in the tunic in small amounts. On the contrary, the minor compounds 19-21, only present in the internal part of the colony, are presumably precursors or, alternatively, could derive from symbiotic microbes [50]. No data are reported about the antimicrobial properties of compounds 19-21. Rossinone B (18) was also tested on cultures of an unidentified sympatric Antarctic marine bacterium. Interestingly, although it was active towards cosmopolitan bacterial strains [48], it revealed no activity in this assay [50].

\subsection{Saturated and Unsaturated Amino Alcohols}

The significant antimicrobial and cytotoxic potential of marine derived saturated and unsaturated amino alcohols stimulated a great interest toward these metabolites. The first examples of amino alcohols with antimicrobial activity from ascidians are the crucigasterins, firstly isolated from the Mediterranean ascidian Pseudodistoma crucigaster [51,52]. The selected crucigasterins described in this review (compounds 22-26, Figure 5) all feature a 2-amino-3-alcohol terminal group of an unsaturated alkyl chain endowed with mixed $E / Z$ geometries of the double bonds. They differ in the carbon chain 
length and the oxidation degree; compounds 25 and 26 possess the 1,2-syn relative configuration at the amino alcohol moiety whereas for compounds 22-24, the 1,2-anti configuration is reported [51,52].
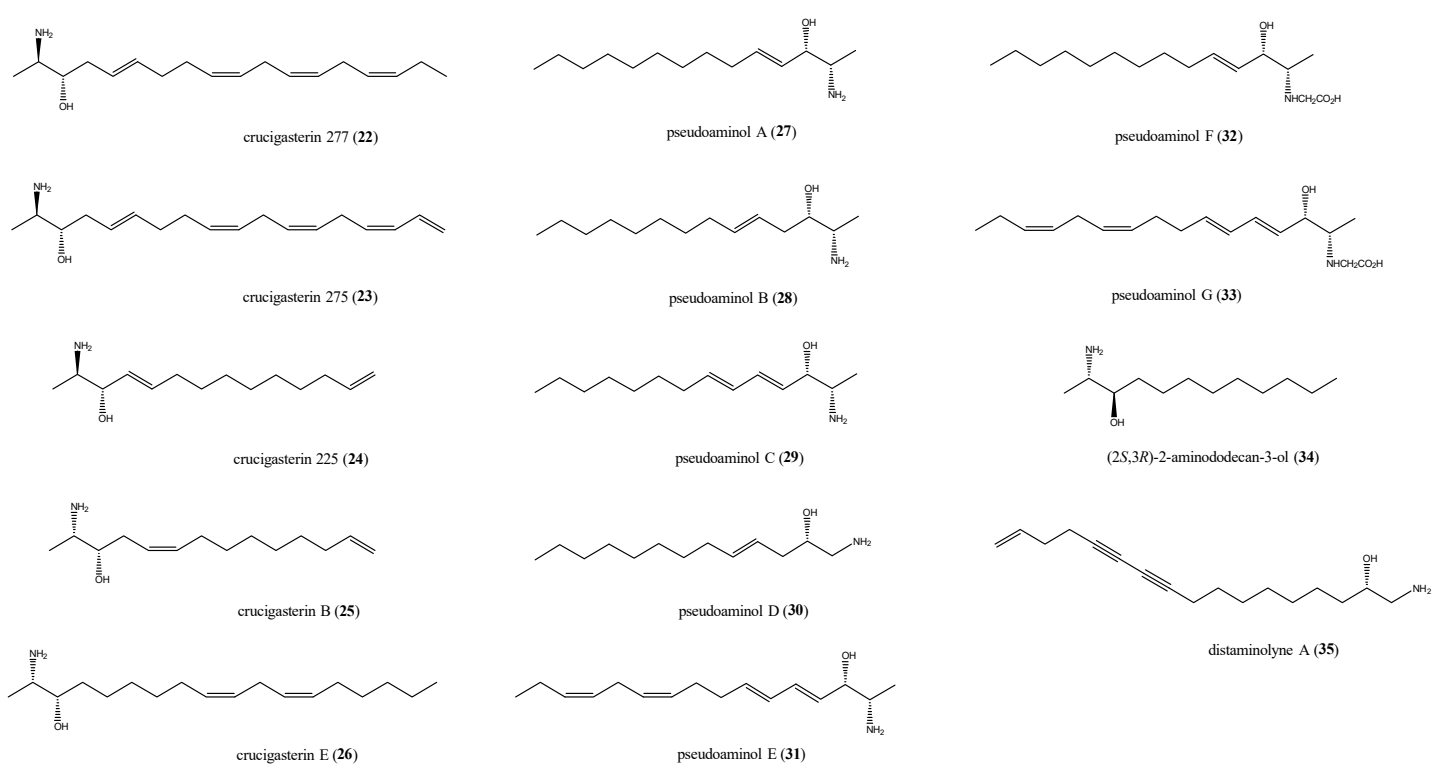

distaminolyne A (35)

Figure 5. Structures of the amino alcohols crucigasterins (22-26), pseudoaminols (27-33), $(2 S, 3 R)$-2-aminododecan-3-ol (34), and distaminolyne A (35).

Biosynthetic studies strongly suggested that these derivatives are produced starting from both fatty acids and either L- or D-alanine. The $2 R$ absolute configuration in compounds 22-24 implied that they should derive from $\mathrm{D}$-alanine, whereas crucigasterins $\mathrm{B}$ and $\mathrm{E}$ are L-alanine derivatives $[53,54]$. Crucigasterins 22-24 showed similar effects against B. subtilis, with inhibition zones of 10, 9, and $9 \mathrm{~mm}$, respectively, at $10 \mu \mathrm{g} /$ disk each. Slight differences were indeed observed for the antifungal activity when compounds 22-24 were tested against the yeast $S$. cerevisiae at $5 \mu \mathrm{g} /$ disk; compound 22 was the most active in the series, with a $12 \mathrm{~mm}$ inhibition zone, whereas crucigasterins 23 and 24 induced $15 \mathrm{~mm}$ and $17 \mathrm{~mm}$ inhibition, respectively [52]. Crucigasterin B (26) was selectively active against the Gram-negative bacterium E. coli at $100 \mu \mathrm{g} / \mathrm{mL}$ and did not exhibit any effect against the yeast C. albicans. Crucigasterin B (25), instead showing both antibacterial and antifungal properties at $50 \mu \mathrm{g} / \mathrm{mL}$.

Pseudoaminols A-G (27-33, Figure 5), obtained from a Pseudistoma sp. collected along the Korean coasts [55], possess structures closely related to those of crucigasterins. Pseudoaminols F (32) and G (33) are the first report of glycine-derived amino alcohols, as attested by the presence, in their structures, of a $\mathrm{N}$-carboxymethyl group [55]. All compounds $\mathbf{2 7 - 3 3}$ were screened for their antibacterial activity against strains of Gram-positive and Gram-negative bacteria. Pseudoaminols A and B (27 and 28) displayed significant activity against all the tested bacterial strains except for E. coli (Table 1); the effects were similar for the two compounds except for Salmonella typhimurium, where $\mathbf{2 7}$ was more potent than 28 (Table 1). Both pseudoaminols A and B were slightly cytotoxic against pulmonary adenocarcinoma A549 and chronic myeloid leukaemia K562 cell lines, too [55].

The reduction of polarity and/or basicity of the amino and hydroxyl groups, for example, with the introduction of a $\mathrm{N}$-carboxymethyl substituent, as in the inactive compounds 32 and 33, emphasizes the crucial role played by these functions in the bioactivity either for electronic effects or steric hindrance [55]. Moreover, the above data suggest that the number of double bonds in the amino alcohols alkyl chain strongly affects the antimicrobial activity, too; if within the group of pseudoaminols, it seems that, as the number of double bonds increases, the activity decreases [55], and the saturated amino alcohol (2S, 3R)-2-aminododecan-3-ol (34, Figure 5), isolated from a sample of Clavelina oblonga when tested on both oxacillin-resistant and sensitive strain of S. aureus, was inactive. It showed indeed 
a strong antifungal activity against $C$. albicans $(\mathrm{MIC}=0.7 \pm 0.05 \mu \mathrm{g} / \mathrm{mL}$ ) and a moderate effect against C. glabrata $(\mathrm{MIC}=30.0 \mu \mathrm{g} / \mathrm{mL})[56]$.

Table 1. Minimum inhibitory concentration (MIC) values expressed in $\mu \mathrm{g} / \mathrm{mL}$ of pseudoaminols A (27) and B (28) against bacteria and human cancer cell lines.

\begin{tabular}{|c|c|c|c|c|c|}
\hline \multirow{2}{*}{ Bacterial Strains } & \multicolumn{2}{|c|}{$\operatorname{MIC}(\mu \mathrm{g} / \mathrm{mL})^{a}$} & \multirow{2}{*}{ Mammalian Cell Line } & \multicolumn{2}{|c|}{$\mathrm{LC}_{50}(\mu \mathrm{M})^{\mathrm{b}}$} \\
\hline & 27 & 28 & & 27 & 28 \\
\hline S. aureus & 12.5 & 12.5 & A549 & 13.8 & 13.1 \\
\hline B. subtilis & 25 & 25 & K562 & 13.6 & 12.6 \\
\hline M. luteus & 12.5 & 12.5 & & & \\
\hline S. typhimurium & 6.25 & 12.5 & & & \\
\hline P. vulgaris & 25 & 25 & & & \\
\hline E. coli & $>100$ & $>100$ & & & \\
\hline
\end{tabular}

a Ampicillin has been used as positive control with MIC of $0.4 \mu \mathrm{g} / \mathrm{mL}$ against $S$. aureus, B. subtilis, $M$. luteus, and S. typhimurium; $1.6 \mu \mathrm{g} / \mathrm{mL}$ against $P$. vulgaris; $6.3 \mu \mathrm{g} / \mathrm{mL}$ against $E$. coli. ${ }^{\mathrm{b}}$ Doxorubicin as positive control with $\mathrm{LC}_{50}$ $(\mu \mathrm{M})$ of 0.9 (A549) and 1.1 (K562).

The one example of antimicrobial acetylenic amino alcohol is distaminolyne A (35) from P. opacum (Figure 5) [57]. Compound 35 showed MIC values of $32 \mu \mathrm{g} / \mathrm{mL}(85 \mu \mathrm{M})$ against S. aureus and Mycobacterium tuberculosis, and of $64 \mu \mathrm{g} / \mathrm{mL}(170 \mu \mathrm{M})$ against E. coli. Using microbroth dilution assay, a bactericidal effect was demonstrated for the amino alcohol 35, with a minimum bactericidal concentration (MBC) of $32 \mu \mathrm{g} / \mathrm{mL}$ against $S$. aureus, of $64 \mu \mathrm{g} / \mathrm{mL}$ against M. tuberculosis, and $\mathrm{MBC}>128 \mu \mathrm{g} / \mathrm{mL}$ against E. coli.

\subsection{Spiroketals}

The spiroketal moiety widely occurs in bioactive natural products [58-61]. Within the marine environment, Didemnum ascidian species has been the source of unique didemnaketals [62-65], never previously isolated by other marine species. Didemnaketals D and E (36 and 37) featuring a spiroketal/ketal (36) or a spiroketal/hemiketal moiety (37), as well as didemnaketals F (38) and G (39) in which a methyl ketone moiety replaced the terminal ester present in $\mathbf{3 6}$ and 37, were tested for their antimicrobic activity (Figure 6).

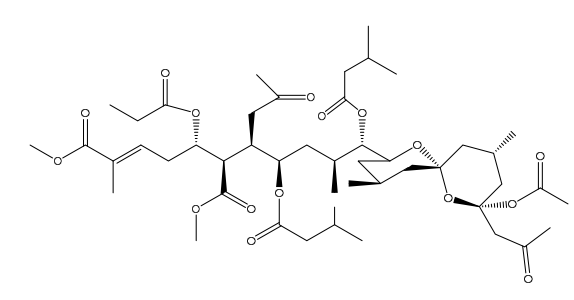

didemnaketal D (36)

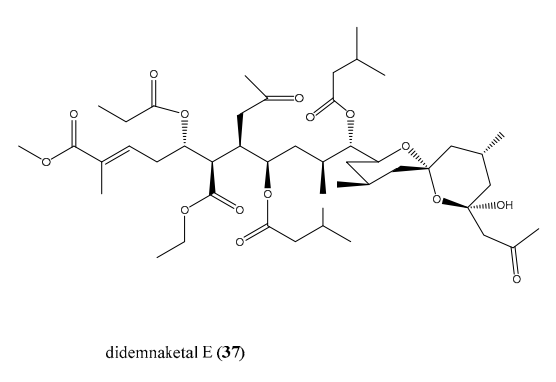

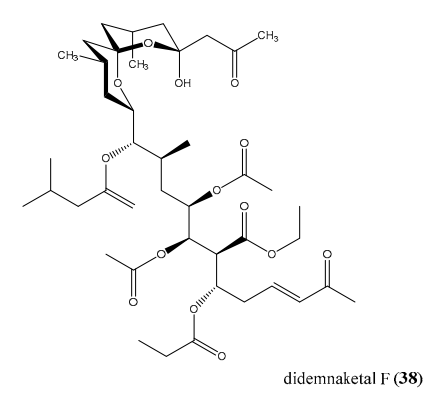

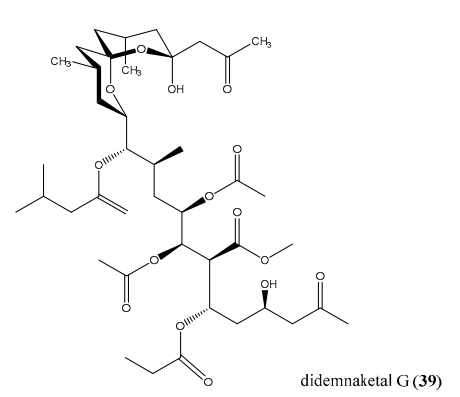

Figure 6. Structures of didemnaketals D-G (36-39). 
Didemnaketals D (36) and E (37) were not effective as antifungal and moderately active against S. aureus and B. subtilis, with an $11 \mathrm{~mm}$ of inhibition zone each [64]. Didemnaketals F (38) and G (39) were active against both E. coli and C. albicans; 38 displayed a stronger antimicrobial activity, showing 20 and $24 \mathrm{~mm}$ inhibition zones, respectively, at $100 \mu \mathrm{g} / \mathrm{disc}$ ( 39 was moderately active against these pathogens with 7 and $17 \mathrm{~mm}$ of inhibition zones, respectively, at the same concentration) [65]. Didemnaketals displayed further bioactivities, such as kinases inhibition [64] and cytotoxic properties [65].

\subsection{Peptides and Peptide-Like Structures}

Antimicrobial peptides (AMPs) of marine origin have recently attracted great attention of the scientists for their numerous bioactivities and applications [66-68]. Generally, they are rather small peptides ( $<60$ amino acids) with various anti-infective activities against different microorganisms, including Gram-positive and Gram-negative bacteria, fungi, viruses, and parasites [69]; some of them possess anticancer and immunomodulating activities [68]. Marine AMPs represent for the host organisms the first line of defense against invading microbes, and it has been hypothesized that AMPs' antimicrobial activity is based on their initial electrostatic interaction with the negatively-charged surface of the bacteria [66,70]. Despite the chemical diversity of marine AMPs, a broad classification has been proposed, based on some key structural features and biochemical characteristics shared by most AMPs. They have thus been divided into four general categories, namely, (a) linear $\alpha$-helical peptides; (b) linear or helical peptides with abundance of one amino acid (proline, tryptophan, histidine, or glycine rich peptides); (c) peptides forming hairpin-like $\beta$-sheet or $\alpha$-helical/ $\beta$-sheet mixed structures stabilized by intramolecular disulfide bonding; and (d) cyclic peptides [68]. Several AMPs have been isolated from ascidians, all belonging to the linear $\alpha$-helical peptides category [68]. The solitary ascidian Styela clava has been the source of two distinct families of $\alpha$-helical AMPs, the styelins, and the clavanins, small peptides $(2-4 \mathrm{kDa})$ that were identified from the blood cells (hemocytes) of the ascidian [71-73]. The styelins are phenylalanine-rich peptides with 32 amino acid residues, whereas the clavanins are histidine-rich polypeptides with cationic properties with 23 amino acid residues and C-terminal amidation [71-74]. Styelins killed the marine bacteria Psychrobacter immobilis and Planococcus citreus in media containing $\mathrm{NaCl}(0.4 \mathrm{mM})$; styelins A and B showed also significant activity (MIC $\leq 0.5 \mu \mathrm{M}$ ) against both Gram-negative (E. coli, S. typhimurium, P. aeruginosa) and Gram-positive (Listeria monocytogenes, E. faecium, S. aureus) bacteria [71,72]. Styelin D also was active against Gram-negative and Gram-positive bacteria and was hemolytic and quite cytotoxic to eukaryotic cells [73].

In clavanins A-E, 18 of the 23 amino acid residues are identical, and 4 or 5 are phenylalanine residues. Clavanins were active against infections by fungi and Gram-positive (including multi-resistant S. aureus (MRSA)) and Gram-negative bacteria. It has been reported that, when clavelin A is used in a nanoparticle formulation, it shows an increase in its antimicrobial activity and has the potential to be used to treat polymicrobial sepsis infections caused by S. aureus, E. coli, P. aeruginosa, and/or K. pneumoniae [75]. In vivo sepsis bioassays, performed using C57BL6 mice strain inoculated with a polymicrobial suspension, led to a $100 \%$ survival rate under sub-lethal sepsis assays and $40 \%$ under lethal sepsis assays in the presence of nanoformulated clavanin A [75]. The clavanins showed optimal antibacterial efficacy at acidic $\mathrm{pH}(\mathrm{pH}=5.5)$, unlike that of styelins, which demonstrated a broad $\mathrm{pH}$ optimum in killing bacteria [73].

Halocyntin and papillosin, two cationic AMPs isolated from the hemocytes of a Mediterranean Sea collection of $H$. papillosa showed strong activity against a panel of both Gram-positive and Gram-negative bacteria [76]. Papillosin (range of activity: $0.05 \mu \mathrm{M}<\mathrm{MBC}<6.25 \mu \mathrm{M}$ ) was eight times more active than halocyntin (range of activity: $0.39 \mu \mathrm{M}<\mathrm{MBC}<50 \mu \mathrm{M}$ ); for both compounds, a low protein binding potential was evidenced, indicating their ability to interact selectively with the lipids of the microbial membrane and not with proteins [76].

Two cysteine-containing $\alpha$-helical AMPs have been isolated from H. aurantium, the homodimer dicynthaurin [77], composed of two 30-residue monomers without any sequence homology to other 
marine ascidian peptides, and the heterodimer halocidin [78], composed of two subunits containing 18 and 15 amino acid residues that are linked by a single disulfide bond. Dicynthaurin was active against Gram-positive (M. luteus, L. monocytogenes, S. aureus) and Gram-negative bacteria (E. coli, P. aeruginosa) at $140 \mu \mathrm{g} / \mathrm{mL}$ (MIC). Furthermore, it possesses antibiotic activity optimal at $\mathrm{NaCl}$ concentrations below $100 \mathrm{mM}$, suggesting that its activities may take place intracellularly rather than extracellularly. Halocidin was shown to be effective against two antibiotic-resistant bacteria, S. aureus and P. aeruginosa [78], and demonstrated potent antifungal activity, too (MIC $=1-4 \mathrm{mg} / \mathrm{mL}$ ) [79]. It is to be noted that the 18-monomer subunit is more active than the heterodimer or the 15-monomer against MRSA and multi-drug resistant P. aeruginosa [80]. Very recently, novel AMPs, turgencins A and B, along with some their oxidized derivatives have been identified from the Arctic ascidian Synoicum turgens, and they represent the first cysteine-rich AMPs isolated from ascidians [81]. All turgecins showed antibacterial activity against both Gram-negative and Gram-positive bacterial strains, but to a different extent. Turgencin AMox1 is the most potent compound in the series, with MICs values of $0.4 \mu \mathrm{M}$ against both Corynebacterium glutamicum and B. subtilis, and of $0.8 \mu \mathrm{M}$ against E. coli. Turgencin AMox1 was also cytotoxic, but the MIC against the most sensitive bacteria is still 12 times lower than the $\mathrm{IC}_{50}$ against the non-malignant cell line [81].

Peptide-like compounds have also been recovered from marine ascidians, some of them belonging to the tunichrome family, a class of reducing 3,4-dihydroxyphenylalanine (DOPA)-containing peptides present in the blood cells of ascidians [82]. Unusual members of this group are halocyamines A (40) and B (41), two tetrapeptide-like compounds containing L- DOPA and a 6-bromoindole DOPA (Figure 7), isolated from the ascidian H. roretzi collected in Mutsu Bay, Japan [83,84]. Biological evaluation of halocyamines A and B showed a wide range of activities, including growth inhibition of Gram-positive bacteria, Gram-negative marine bacteria, fungi, and fish RNA viruses [85]. However, when halocyamine A (40) was evaluated against a panel of Gram-positive (S. aureus, S. intermedius), Gram-negative (P. aeruginosa E. coli ATCC, E. faecalis), and marine Gram-negative bacteria (V. harveyi, $V$. alginolyticus and Listonella anguillarum), it showed a modest antibacterial activity and only against P. aeruginosa and E. faecalis (for both $\mathrm{MIC}=100 \mu \mathrm{M}$ ) and V. harveyi $\left(\mathrm{IC}_{50}=129 \mu \mathrm{M}\right.$ ).
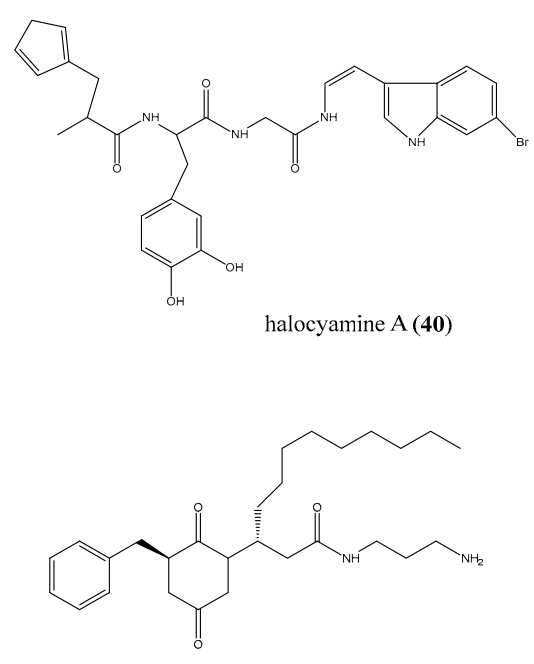

rodriguesine A (42)
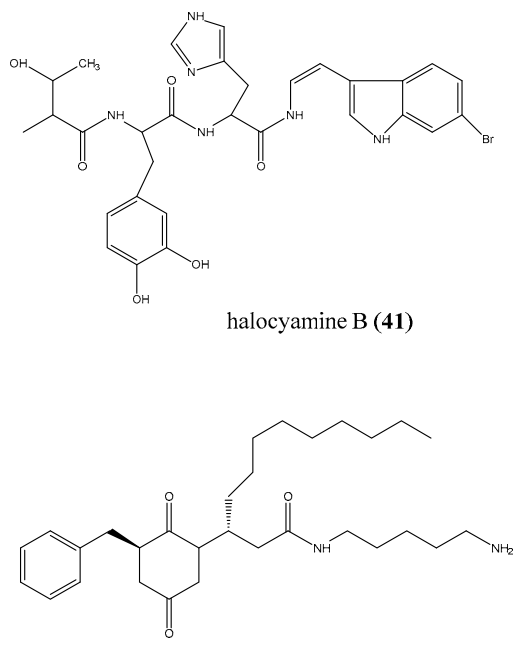

rodriguesine $\mathrm{B}(\mathbf{4 3})$

Figure 7. Structures of the peptide-like compounds halocyamines (40 and 41 ), and of rodriguesines A and $B(42$ and 43$)$.

From a Didemnum sp., two modified diketopiperazines, rodriguesines A and B (42 and 43, Figure 7), were isolates as a mixture of inseparable homologues [86]. Both 42 and 43 displayed moderate antibiotic activity against most of the tested pathogen except against P. aeruginosa P1 $(\mathrm{MIC}=4.3 \mu \mathrm{g} / \mathrm{mL})$. Interestingly, the mixture of diketopiperazines was proven to be more active 
against antibiotic-resistant strains than against standard American Type Culture Collection (ATCC) or National Collection of Type Culture (NCTC) strains and also inhibited both oral streptococci and pathogenic bacteria. It has also been reported that rodriguesines were able to inhibit $S$. mutans biofilm formation, downregulating the expression of the bacterium virulence genes gtfB, gtfC, and gbpB without affecting the expression of the house-keeping genes groEL and 16S [87].

\subsection{Alkaloid Structures}

Ascidians are known to be a rich source of bioactive alkaloids, many of them with antimicrobial properties, suggesting their potential value as lead structures for the development of new antibiotics [88-90]. Among these, $\beta$-carbolines form a large group of tryptophan-derived metabolites frequently isolated from ascidians belonging to several taxonomical groups, mainly from Eudistoma species [57,91-93]. Eudistomins and didemnolines are members of this family of metabolites and some of them exhibited interesting antimicrobial activity. Several eudistomins were obtained from the extract of the colonial Caribbean ascidian E. olivaceum. Eudistomins D, I, N, O, P, and Q (44-49, Figure 8) exhibited modest activity against B. subtilis [94,95]. However, for eudistomins I, N, O (45-47), $\mathrm{H}$ (50), and M (51) (Figure 8), previously reported as "moderately active" against viruses and bacteria, a photo-induced effect was observed. These five eudistomins (45-47, 50, and 51) were active or more significantly active under ultraviolet A (UVA) exposure against murine cytomegalovirus, Sindbis virus, S. cerevisiae, S. albus, B. subtilis, E. coli, and mammalian 3T3 cells [96]. The antibacterial, antifungal, and antiviral effects were indeed not correlated, suggesting different mechanisms of action against different microorganism, depending upon the presence or absence of UVA [96].

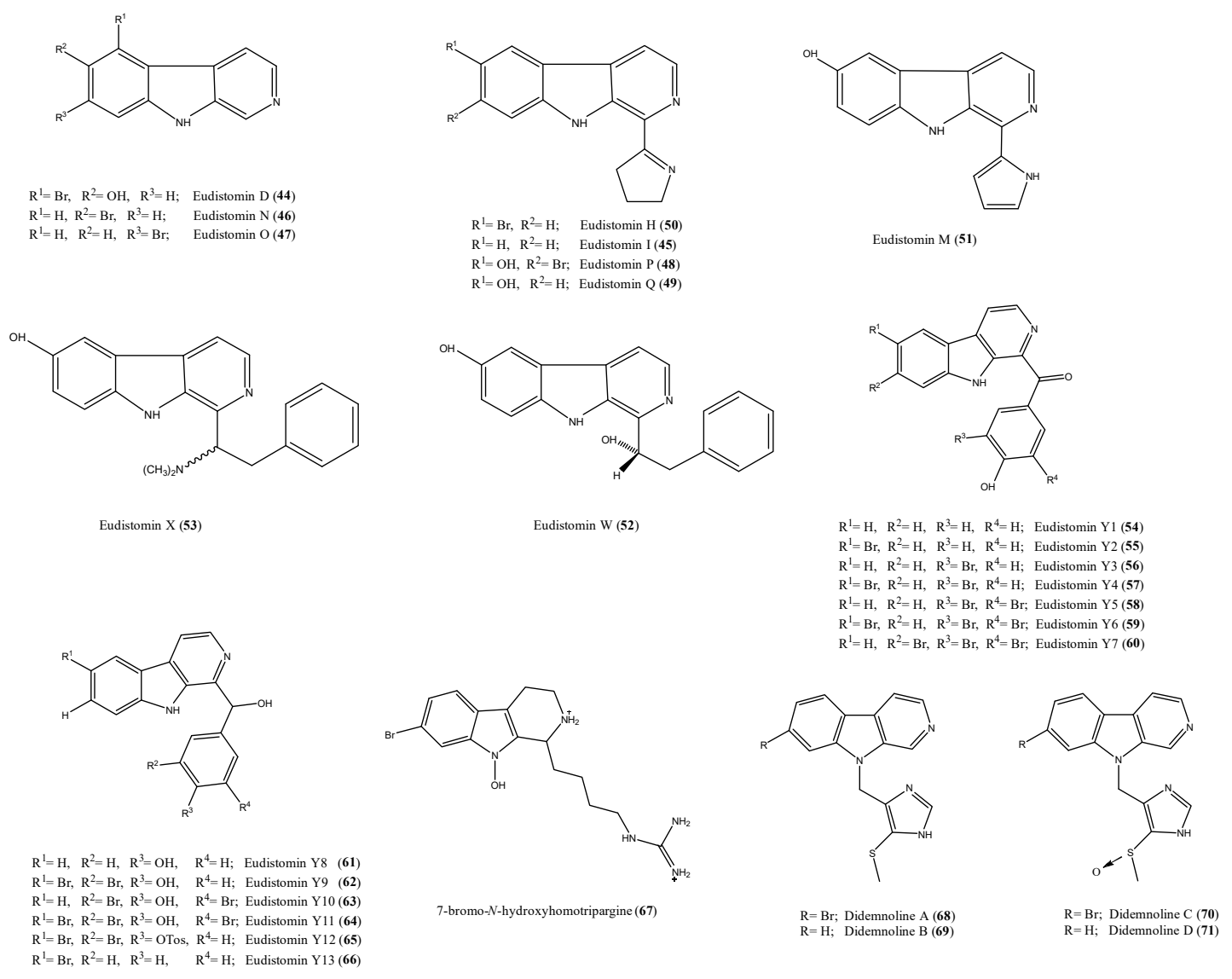

Figure 8. Structures of the $\beta$-carbolines alkaloids eudistomins (44-66), 7-Bromo- $N$-hydroxyhomotrypargine (67), and didemnolines A-D (68-71). 
Eudistomins W and X (52 and 53, Figure 8) were obtained from a Micronesian Eudistoma sp. [97]. Compound 53 showed antibacterial activity against B. subtilis (17 and $18 \mathrm{~mm}$ of inhibition zones), S. aureus (11 and $12 \mathrm{~mm}$ ), and E. coli (15 and $20 \mathrm{~mm}$ ) at loading doses of 5 and $10 \mu \mathrm{g}$ per disk, respectively, and fungicidal against C. albicans, with inhibition zones of 17 and $18 \mathrm{~mm}$ at similar loading doses, too. On the contrary, eudistomin W (52) was selectively active toward C. albicans, giving a zone of inhibition of $13 \mathrm{~mm}$ at $10 \mu \mathrm{g}$.

Further, eudistomins (eudistomin Y1-Y7, 54-60, Figure 8) have been isolated from a South Sea collection of Eudistoma sp. [91]. In this study, eudistomin Y6 (59) was shown to be moderately active against S. epidermis and B. subtilis. Eudistomins Y2-Y7 (55-60) were re-isolated from the Korean ascidian Synoicum sp., together with other derivatives, eudistomins Y8-Y13 (61-66, Figure 8) [93]. Eudistomin Y10 (63) showed a potent inhibition against various bacterial strains such as $B$. subtilis $(12.5 \mu \mathrm{g} / \mathrm{mL})$ and Proteus vulgaris $(12.5 \mu \mathrm{g} / \mathrm{mL})$. Moreover, eudistomin Y7 (60) showed anti-fungal activity on Aspergillus fumigatus $(50 \mu \mathrm{g} / \mathrm{mL})$ and Trichophyton rubrum $(50 \mu \mathrm{g} / \mathrm{mL})$.

7-Bromo-N-hydroxyhomotrypargine (67, Figure 8) was isolated from the New Zealand ascidian P. opacum [57]. It exhibited significant activity toward S. aureus in microbroth-dilution assays with MIC and MBC values of $32 \mu \mathrm{g} / \mathrm{mL}(53 \mu \mathrm{M})$, but was less active against E. coli (MIC $64 \mu \mathrm{g} / \mathrm{mL}$, $\mathrm{MBC}>64 \mu \mathrm{g} / \mathrm{mL}[106 \mu \mathrm{M}]$ ) and inactive toward $M$. tuberculosis BSG001 (MIC and MBC $>64 \mu \mathrm{g} / \mathrm{mL}$ [106 $\mu \mathrm{M}]$ ). In addition, compound 67 exhibited a moderate antimalarial activity; in particular, it was tested against a chloroquine-resistant strain (FcB1-Colombia) of Plasmodium falciparum and found to exhibit an $\mathrm{IC}_{50}$ value of $3.8 \mu \mathrm{M}$. Thus, the $\beta$-carboline system is an additional example of a new marine derived chemical scaffold useful for development of antimalarial agents [40,41,98-101].

Didemnolines A-D 68-71 (Figure 8) were isolated from the ascidian Didemnum sp., collected in Northern Mariana Islands (USA) [92]. When tested against several bacterial strains, only didemnoline $C$ (70) showed $7 \mathrm{~mm}$ and $9 \mathrm{~mm}$ growth inhibition zones against E. coli and S. aureus, respectively [92].

Pyridoacridines isolated from ascidians are typically tetra- or penta-cyclic aromatic alkaloids based on the pyrido[k,l]acridine skeleton with a broad range of bioactivities including cytotoxic, antibacterial, antifungal, antiviral, insecticidal, anti-HIV, and anti-parasitic [88,102,103]. Examples of antimicrobial piridoacridines are isodiplamine (72), cystodytin K (73), lissoclinidine (74), diplamine (75), and cystodytin J (76) (Figure 9) from Lissoclinum notti [104], active towards a variety of microorganisms, including the bacteria B. subtilis and E. coli and the fungi C. albicans and Trichophyton mentagrophytes. Several antimicrobial pyridoacridine alkaloids have been reported from Cystodytes dellechiajei, a colonial soft-bodied ascidian widely distributed in tropical and temperate waters, which occurs in a range of colour morphs [105-111]. Interestingly, chemical investigation of ascidian different color morphs yielded different piridoacridine structures. Bry et al. reported the isolation from a purple chromotype from Mediterranean sea of 13-didemethylaminocycloshermilamine D (77) and demethyldeoxyamphimedine (78) (Figure 9) [112]. Both pyridoacridines (77 and 78) were tested against the marine bacterial strain L. anguillarum $(7.0<\mathrm{MIC}$ value range $<9.0 \mu \mathrm{M})$ and the terrestrial bacterial strain $M$. luteus $(6.5<\mathrm{MIC}$ value range $<7.0 \mu \mathrm{M})$, showing an activity against the two strains in the order of micromolar with less activity on the marine strain. A purple colour morph collected in Catalonia afforded kuanoniamine D (79), shermilamine B (80), N-deacetylkuanoniamine D (81), styelsamine C (82), and N-deacetylshermilamine B (83) [113-116]. Some green colour morphs yielded 11-hydroxyascididemin (84) [108,109], 8,9-dihydro-11-hydroxyascididemin (85) [117], cystodimine A (86), and cystodimine B (87) [107], while, from the extract of a blue morph, only ascididemin (88) was obtained (Figure 9) [106,107]. Ascididemin was found to be active against E. coli, Cladosporium resinae, and B. subtilis, but inactive toward P. aeruginosa and T. mentagrophytes [118]. Each compound was tested against two bacterial strains E. coli and M. luteus and a dose-dependent inhibition was observed for all tested pyridoacridines against the two strains. The MIC values ranged from 0.2 to $2.6 \mu \mathrm{M}$ toward E. coli and from 0.3 to $17.4 \mu \mathrm{M}$ toward M. luteus. 
<smiles></smiles>

$\mathrm{R}^{1}=\mathrm{H}, \mathrm{R}^{2}=\mathrm{H}, \mathrm{R}^{3}=\mathrm{SCH}_{3}$; isodiplamine (72) $\mathrm{R}^{1}=\mathrm{H}, \mathrm{R}^{2}=\mathrm{OCH}_{3}, \mathrm{R}^{3}=\mathrm{H} ;$ cystodytin $\mathrm{K}(\mathbf{7 3})$ $\mathrm{R}^{1}=\mathrm{SCH}_{3}, \mathrm{R}^{2}=\mathrm{H}, \mathrm{R}^{3}=\mathrm{H}$; diplamine (75) $\mathrm{R}^{1}=\mathrm{H}, \mathrm{R}^{2}=\mathrm{H}, \mathrm{R}^{3}=\mathrm{H}$; cystodytin $\mathrm{J}(76)$

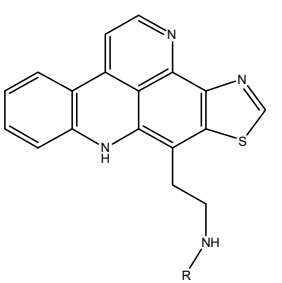
$\mathrm{R}=\mathrm{COCH}_{3}$; kuanoniamine $\mathrm{D}(\mathbf{7 9})$ $\mathrm{R}=\mathrm{H} ; \mathrm{N}$-deacetylkuanoniamine $\mathrm{D}(\mathbf{8 1})$

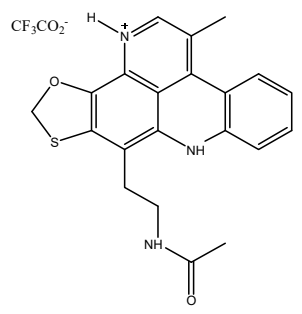

lissoclinidine (74)<smiles>CNCCc1c2c(c3nccc4c3c1-c1ccccc1N4)NC(=O)C(=O)CS2</smiles>

$\mathrm{R}=\mathrm{COCH}_{3}$; shermilamine $\mathrm{B}(\mathbf{8 0})$ $\mathrm{R}=\mathrm{H}$; N-deacetylshermilamine $\mathrm{B}(\mathbf{8 3})$<smiles>O=C1CCNC2=C1C(=O)c1nc3ccccc3c3ccnc2c13</smiles>

8,9-dihydro-11-hydroxyascididemin (85)<smiles>O=C1CSc2c(cc3c4c(ccnc24)-c2ccccc2-3)N1</smiles>

13-didemethylaminocycloshermilamine D (77)<smiles>O=Cc1cc(O)c2nccc3c2c1Nc1ccccc1-3</smiles>

styelsamine C (82)<smiles>N=C1C2=C(NCCC2=O)c2nccc3c2c1nc1ccc(P)cc13</smiles>

$\mathrm{R}=\mathrm{H} ;$ cystodimine $\mathrm{A}(\mathbf{8 6})$
$\mathrm{R}=\mathrm{OH} ;$ cystodimine $\mathrm{B}(\mathbf{8 7})$<smiles>O=C1c2cnccc2-c2nc3ccccc3c3ccnc1c23</smiles>

demethyldeoxyamphimedine (78)<smiles>O=C1c2c(Br)ccnc2-c2nccc3c2c1nc1ccccc13</smiles>
$\mathrm{R}=\mathrm{OH} ;$ 11-hydroxyascididemin $(\mathbf{8 4}$
$\mathrm{R}=\mathrm{H}$; ascididemin $(\mathbf{8 8})$

Figure 9. Structures of the pyridoacridine alkaloids 72-88.

Piclavines A-C (89-91, Figure 10) are isomeric indolizidine alkaloids isolated from the ascidian Clavelina picta [119]. Piclavines differ in the number of double bonds on the side chain and each group is composed of an inseparable mixture of stereoisomers, which differ for both the configuration at $\mathrm{C} 2$ and geometry at the double bond. The piclavines A-C are the first indolizidines isolated from a marine source; they exhibited a pronounced antifungal and antimicrobial activity against Gram-positive bacteria (C. albicans, Geotrichium candidum, A. terreus, S. aureus, B. cereus, Corynebacterium michiganensis), while none of the Gram-negative bacteria tested (E. coli, P. aeruginosa, and X. campestrum) showed any response toward these indolizidines.

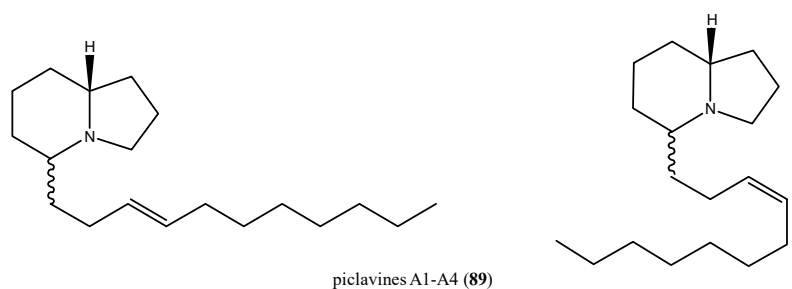

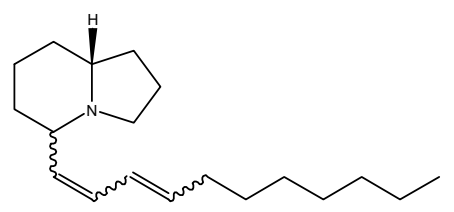

piclavines B (90)

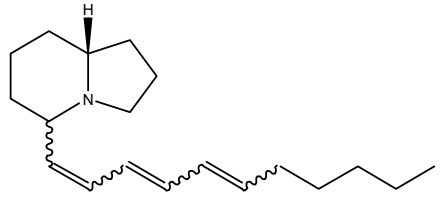

piclavines C (91)

Figure 10. Structures of the indolizine alkaloids piclavines (89-91). 
Marine natural products incorporating a guanidine functionality are not uncommon, and often exhibit interesting biological activities [120]. An example is tubastrine (92), firstly isolated from a coral [121], but successively found in the ascidians Dendrodoa grossularia, Ascidiella scabra, and Aplidium orthium (Figure 11) [122,123]. Tubastrine (92) showed antiviral activity against Herpes simplex virus type I and vesicular stomatitis virus [121], besides anticancer and anti-inflammatory activity [123]. 3-Dehydroxytubastrine (93) is a closely turbastrine-related compound isolated from the sub-Arctic ascidian Dendrodoa aggregate [124]. It showed antimicrobial activity against several bacteria such as Corynebacterium glutamicum, S. aureus, and methicillin-resistant S. aureus (MRSA), at a concentration of $100 \mu \mathrm{g} / \mathrm{mL}$ [124], as well as against Serratia (500 $\mu \mathrm{g} /$ disk) and E. coli (100 $\mu \mathrm{g} / \mathrm{disk})$ [125].<smiles>N=C(N)N/C=C/c1ccc(O)c(O)c1</smiles>

tubastrine $(\mathbf{9 2})$<smiles>N=C(N)N/C=C/c1ccc(O)cc1</smiles>

3-dehydroxytubastrine (93)

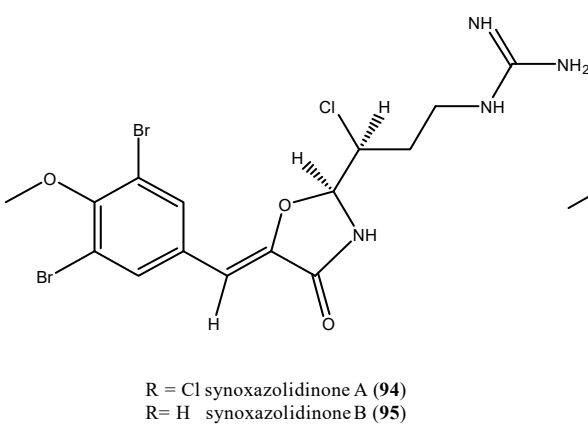<smiles>COc1c(Br)cc(/C=C2\O[C@]3(C)C(=O)N2[C@H](CN=C(N)N)C[C@@H]3Cl)cc1Br</smiles>

synoxazolidinone C (96)

Figure 11. Structures of the guanidine alkaloids tubastrine (92), 3-dehydroxy tubastrine (93), and synoxazolidinones A-C (94-96).

Synoxazolidinones A-C (94-96, Figure 11) form a family of dibrominated guanidines containing a unique 4-oxazolidinone core structure, which were isolated from S. pulmonaria collected off the Norwegian coast $[126,127]$. Synoxazolidinone A (94) displayed activity against the Gram-positive bacteria S. aureus, MRSA, with MIC values of $10 \mu \mathrm{g} / \mathrm{mL}$ each, and against C. glutamicum with an MIC value of $6.25 \mu \mathrm{g} / \mathrm{mL}$. It was also effective against S. cerevisiae (MIC $=12.5 \mu \mathrm{g} / \mathrm{mL}$ ). Synoxazolidinone B (95) was less potent than synoxazolidinone A (94) against MRSA with an MIC of $30 \mu \mathrm{g} / \mathrm{mL}$; this suggested that the chlorine atom is important for the biological activity [126]. Synoxazolidinone C (96) exhibited the same antibacterial potency of synoxazolidinone A (94) on S. aureus and MRSA (MIC $=10 \mu \mathrm{g} / \mathrm{mL}$ each) and was active also against $E$. coli and E. faecalis at concentrations of 30 and $20 \mu \mathrm{g} / \mathrm{mL}$, respectively [127].

\subsection{Furanones and Other Brominated Aromatic Derivatives}

Rubrolides and cadiolides are two families of structurally related halogenated aromatic compounds endowed with a central furanone ring isolated from different marine ascidians such as Ritterella, Pseudodistoma, Botryllus, and Synoicum [128-133]. Two rubrolides have also been found into a culture of the fungus Aspergillus terreus [134]. These compounds possess a number of bioactivities, including anti-inflammatory, cytotoxic, as well as inhibitory activity against protein phosphatases. Moreover, both these groups of furanone derivatives may be considered as two interesting classes of natural antibiotics.

The first report of antibacterial effects exhibited by rubrolides dates from the biological evaluation of organic extracts from Ritterella rubra specimens [128]. The bioassay-guided fractionation of these extracts led to the identification of rubrolides A-H (97-104, Figure 12) as responsible for the antibacterial effects against $S$. aureus and B. subtilis. The most active compounds in the series were rubrolides 
A-C (97-99), which exhibited MIC values of 9, 2, and $11 \mu \mathrm{g} /$ disk against the two strains, respectively. Rubrolides E and F (101 and 102) were re-isolated from samples of Synoicum sp. collected in South Africa area along with the strictly related compounds $3^{\prime \prime}$-bromorubrolide $\mathrm{F}(\mathbf{1 0 5}), 3^{\prime}$-bromorubrolide $\mathrm{E}$ (106), $3^{\prime}$-bromorubrolide F (107), and $3^{\prime}, 3^{\prime \prime}$-dibromorubrolide E (108) (Figure 12) [132]. The possibility for 101-102 and 105-108 to act against a panel of dangerous bacteria such as MRSA and S. epidermidis as well as gentamycin- and vancomycin-resistant E. faecalis and E. coli strains was investigated. Rubrolide $\mathrm{F}$ (102) and its brominated derivatives 105 and 107 were rather ineffective against all the tested bacteria, whereas rubrolide E (101) and its analogues 106 and 108 showed different effects. Despite being weakly active against MRSA $\left(\mathrm{IC}_{50}=105 \mu \mathrm{M}\right)$, rubrolide $\mathrm{E}$ was the most active compound against S. epidermidis with an $\mathrm{IC}_{50}$ was of $21 \mu \mathrm{M}$, followed by $3^{\prime}, 3^{\prime \prime}$-dibromorubrolide $\mathrm{E}\left(\mathbf{1 0 8}, \mathrm{IC}_{50}=28 \mu \mathrm{M}\right)$ and $3^{\prime}$-bromorubrolide $\mathrm{E}\left(\mathbf{1 0 6}, \mathrm{IC}_{50}=38 \mu \mathrm{M}\right)$. Additionally, 101 exhibited the higher percentage $(89 \%)$ of E. faecalis growth inhibition, whereas it was less potent against $E$. coli ( $16 \%$ of inhibition growth). Its dibrominated derivative (108), instead, was the most potent in the series against $E$. coli with $26 \%$ of growth inhibition with respect to all other compounds, mainly the 3'-bromorubrolide E (106), which was totally inactive against this strain [132].

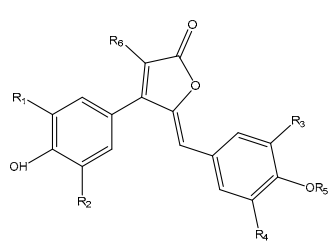

rubrolide $A$ (97): $\mathrm{R}_{1}=\mathrm{R}_{2}=\mathrm{R}_{3}=\mathrm{R}_{4}=-\mathrm{Br} ; \mathrm{R}_{5}=\mathrm{R}_{6}=-\mathrm{H}(Z)$ rubrolide $\mathrm{B}(\mathbf{9 8}): \mathrm{R}_{1}=\mathrm{R}_{2}=\mathrm{R}_{3}=\mathrm{R}_{4}=-\mathrm{Br} ; \mathrm{R}_{5}=-\mathrm{H} ; \mathrm{R}_{6}=-\mathrm{Cl}(Z)$; rubrolide $\mathrm{C}$ (99): $\mathrm{R}_{1}=\mathrm{R}_{2}=\mathrm{R}_{5}=\mathrm{R}_{6}=-\mathrm{H} ; \mathrm{R}_{3}=\mathrm{R}_{4}=-\mathrm{Br}(Z)$ rubrolide $\mathrm{D}(\mathbf{1 0 0}): \mathrm{R}_{1}=\mathrm{R}_{2}=-\mathrm{Br} ; \mathrm{R}_{3}=\mathrm{R}_{4}=\mathrm{R}_{5}=\mathrm{R}_{6}=-\mathrm{H}(\mathrm{Z})$ rubrolide $E$ (101): $\mathrm{R}_{1}=\mathrm{R}_{2}=\mathrm{R}_{3}=\mathrm{R}_{4}=\mathrm{R}_{5}=\mathrm{R}_{6}=-\mathrm{H}(Z)$ rubrolide $\mathrm{F}$ (102): $\mathrm{R}_{1}=\mathrm{R}_{2}=\mathrm{R}_{3}=\mathrm{R}_{4}=\mathrm{R}_{6}=-\mathrm{H} ; \mathrm{R}_{5}=-\mathrm{CH}_{3}(Z)$; 3"-bromorubrolide $\mathrm{F}$ (105): $\mathrm{R}_{1}=\mathrm{R}_{2}=\mathrm{R}_{4}=\mathrm{R}_{6}=-\mathrm{H} ; \mathrm{R}_{3}=-\mathrm{Br} ; \mathrm{R}_{5}=-\mathrm{Et}(Z)$ 3'-bromorubrolide $\mathrm{E}$ (106): $\mathrm{R}_{1}=\mathrm{R}_{3}=\mathrm{R}_{4}=\mathrm{R}_{5}=\mathrm{R}_{6}=-\mathrm{H} ; \mathrm{R}_{2}=-\mathrm{Br}(Z)$; 3'-bromorubrolide $\mathrm{F}$ (107): $\mathrm{R}_{1}=\mathrm{R}_{3}=\mathrm{R}_{4}=\mathrm{R}_{6}=-\mathrm{H} ; \mathrm{R}_{2}=-\mathrm{Br} ; \mathrm{R}_{5}=-\mathrm{Et}(Z)$ 3',3"-dibromorubrolide $\mathrm{E}(\mathbf{1 0 8}): \mathrm{R}_{1}=\mathrm{R}_{4}=\mathrm{R}_{5}=\mathrm{R}_{6}=-\mathrm{H} ; \mathrm{R}_{2}=\mathrm{R}_{3}=-\mathrm{Br}(Z)$ rubrolide $\mathrm{J}(\mathbf{1 0 9})$ : $\mathrm{R}_{1}=\mathrm{R}_{3}=\mathrm{R}_{4}=-\mathrm{Br} ; \mathrm{R}_{1}=\mathrm{R}_{5}=\mathrm{R}_{6}=-\mathrm{H}(Z)$ rubrolide $\mathrm{P}(110): \mathrm{R}_{1}=\mathrm{R}_{2}=-\mathrm{Br} ; \mathrm{R}_{2}=\mathrm{R}_{4}=\mathrm{R}_{6}=-\mathrm{H} ; \mathrm{R}_{5}=-\mathrm{CH}_{3}(E / Z) ;$ rubrolide $\mathrm{Q}$ (111): $\mathrm{R}_{1}=-\mathrm{Br} ; \mathrm{R}_{2}=\mathrm{R}_{3}=\mathrm{R}_{4}=\mathrm{R}_{6}=-\mathrm{H} ; \mathrm{R}_{5}=-\mathrm{CH}_{3}(E / Z)$;

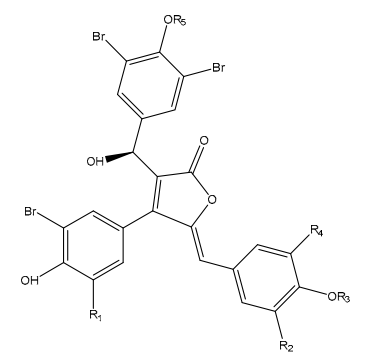

cadiolide $\mathrm{G}$ (117): $\mathrm{R}_{1}=\mathrm{R}_{3}=\mathrm{R}_{4}=\mathrm{R}_{5}=-\mathrm{H} ; \mathrm{R}_{2}=-\mathrm{Br}(Z)$; cadiolide $\mathrm{H}$ (118): $\mathrm{R}_{1}=-\mathrm{Br} ; \mathrm{R}_{2}=\mathrm{R}_{4}=\mathrm{R}_{5}=-\mathrm{H} ; \mathrm{R}_{3}=-\mathrm{CH}_{3}(E / Z)$ cadiolide $\mathrm{J}(\mathbf{1 2 0}): \mathrm{R}_{1}=\mathrm{R}_{2}=-\mathrm{Br} ; \mathrm{R}_{3}=\mathrm{R}_{5}=-\mathrm{CH}_{3} ; \mathrm{R}_{4}=-\mathrm{H}(E / Z)$ cadiolide $\mathrm{K}(\mathbf{1 2 1}): \mathrm{R}_{1}=\mathrm{R}_{2}=-\mathrm{Br} ; \mathrm{R}_{3}=\mathrm{R}_{4}=\mathrm{R}_{5}=-\mathrm{H}(Z)$ cadiolide $\mathrm{L}(\mathbf{1 2 2}): \mathrm{R}_{1}=\mathrm{R}_{3}=-\mathrm{H} ; \mathrm{R}_{2}=\mathrm{R}_{4}=-\mathrm{Br} ; \mathrm{R}_{5}=-\mathrm{CH}_{3}(Z) ;$
cadiolide $\mathrm{M}(\mathbf{1 2 3}): \mathrm{R}_{1}=\mathrm{R}_{2}=\mathrm{R}_{4}=-\mathrm{Br} ; \mathrm{R}_{3}=\mathrm{R}_{5}=-\mathrm{H}(Z)$

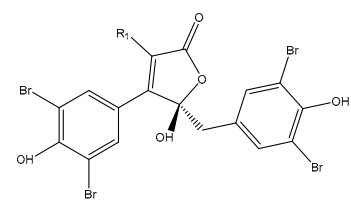

rubrolide $\mathrm{G}(\mathbf{1 0 3})$ : $\mathrm{R}_{1}=-\mathrm{H}$; rubrolide $\mathrm{H}(\mathbf{1 0 4}): \mathrm{R}_{1}=-\mathrm{Cl}$;

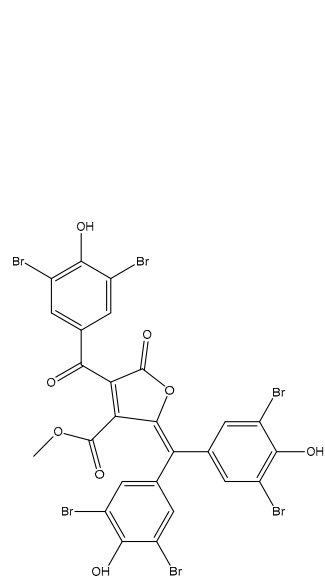

cadiolide I (119)

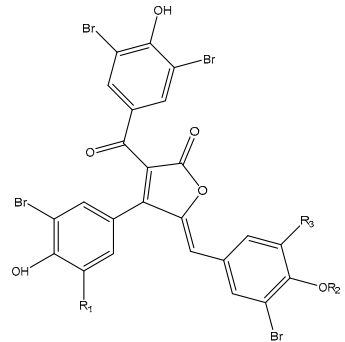

cadiolide $\mathrm{B}(112): \mathrm{R}_{1}=\mathrm{R}_{3}=-\mathrm{Br} ; \mathrm{R}_{2}=-\mathrm{H}(Z)$ cadiolide C (113): $\mathrm{R}_{1}=\mathrm{R}_{2}=\mathrm{R}_{3}=-\mathrm{H}(\mathrm{Z})$ cadiolide $\mathrm{D}(114): \mathrm{R}_{1}=-\mathrm{Br} ; \mathrm{R}_{2}=\mathrm{R}_{3}=-\mathrm{H}(Z)$ cadiolide $\mathrm{F}(116): \mathrm{R}_{1}=-\mathrm{H} ; \mathrm{R}_{2}=-\mathrm{CH}_{3} ; \mathrm{R}_{3}=-\mathrm{Br}(\mathrm{E} / \mathrm{Z})$
;

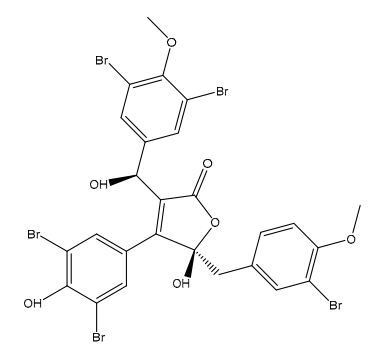

cadiolide $\mathrm{N}(124)$

Figure 12. Structures of the furanone derivatives rubrolides $A-H, J, P$, and $Q(\mathbf{9 7 - 1 1 1 )}$ and cadiolides B-N (112-124).

Rubrolides J (109), P (110), and Q (111) (Figure 12) were obtained from the ascidian P. antinboja [130]. They possessed a weak or moderate antibacterial activity against several Gram-positive bacteria, but they were inactive against Gram-negative strains. Rubrolides $P$ and $Q$ (110 and 111) were inactive against the drug-resistant bacteria strains, and indeed, their $\mathrm{IC}_{50}$ values $(\mu \mathrm{g} / \mathrm{mL})$ were always greater than the cut-off. Nevertheless, they showed some toxic effects only against the Gram-positive actinobacteria Kocuria rhizophila against, which exhibited $\mathrm{IC}_{50}$ of 6.3 and $3.1 \mu \mathrm{g} / \mathrm{mL}$, respectively. More interesting was rubrolide $\mathrm{J}(\mathbf{1 0 9})$, which had $\mathrm{IC}_{50}$ of 0.8 and $1.3 \mu \mathrm{g} / \mathrm{mL}$ against $S$. epidermidis and 
B. subtilis, respectively, and was not toxic against mammalian cells. Rubrolides A and J drew attention as their antibacterial efficacy was comparable to or even better than linezolid and platensimycin when evaluated against several methicillin-sensitive and -resistant $S$. aureus strains [130].

Cadiolides are a family of ascidians secondary metabolites structurally related to rubrolides; they share the same 3-aryl-4-arylmethylenefuranone unit and cadiolides bring up an additional 2-ketoaryl substituent and a different carbon backbone. The family of cadiolides is represented by compounds named from A to N; apart from cadiolide A, the first discovered compound of this class from ascidians of the genus Botryllus for which any bioactivity has not been reported up to now [129], all the remaining cadiolides B-N (112-124, Figure 12) showed antibacterial properties. They have been isolated from specimens of Botryllus sp., P. antinboja, and Synoicum sp. and their biological effects have been investigated [129-131,133,135]. Cadiolides B-N (112-124) were tested against several strains of both Gram-positive and negative bacteria as well as drug-resistant strains; the obtained results evidenced some structural requirements needed for the bioactivity, as described below. Compounds 112-124 did not show any effect on the growth of Gram-negative bacteria such as E. coli, S. typhimurium, and K. pneumoniae, as well as against the Gram-positive E. faecalis and E. faecium. Only cadiolide L (122) inhibited the growth of E. faecalis in vitro, showing an MIC of $8 \mu \mathrm{g} / \mathrm{mL}$ [135].

The antibacterial properties of cadiolides B-N against an array of bacteria strains with related MIC values are reported in Table 2; these data underline their promising potential to be a new class of antibiotics worthy of further investigation. It has been suggested that the hydroxyl group located at C-6 might be more necessary for the antibacterial activity than the ketone group, but not enough experimental evidence has been obtained to support this hypothesis. Surely, the methylation of the phenolic moiety caused an overall reduction of activity against all the tested strains, as demonstrated, for example, for cadiolides F, J, and N when compared with cadiolides C, E, or I. Moreover, the number and the position of bromine atoms is important in term of bioactivity. Generally, cadiolides were antibacterial agents with $\mathrm{IC}_{50}$ values better than or comparable to those of rubrolides. Thus, an additional polysubstituted aromatic ring linked at C-2 may be beneficial to assess the antibacterial potential [130,131,133]. Therefore, the furanone moiety described for these classes of marine natural antibiotics has been recognised as a new active chemotype for the development of more selective and potent antibacterial derivatives considering the novelty of this scaffold with respect to the benchmark antibiotics [130].

Table 2. MIC values $(\mu \mathrm{g} / \mathrm{mL})$ of cadiolides B-N (112-124).

\begin{tabular}{cccccc}
\hline \multirow{2}{*}{ Compounds } & \multicolumn{5}{c}{ MIC $(\mu \mathrm{g} / \mathbf{m L})$} \\
\cline { 2 - 6 } & $\mathbf{A}^{\mathbf{a}}$ & $\mathbf{B}^{\mathbf{a}}$ & $\mathbf{C}^{\mathbf{a}}$ & $\mathbf{D}^{\mathbf{a}}$ & $\mathbf{E}^{\mathbf{a}}$ \\
\hline cadiolide B (112) & 3.1 & 3.1 & 3.1 & $>128$ & $>128$ \\
cadiolide C (113) & 0.4 & 0.2 & 3.1 & 64 & $>128$ \\
cadiolide D (114) & 6.3 & 1.6 & 6.3 & $>128$ & $>128$ \\
cadiolide E (115) & 3.1 & 0.2 & 1.6 & 1.6 & 3.1 \\
cadiolide F (116) & 12.5 & 3.1 & 12.5 & $-\mathrm{b}$ & $-\mathrm{b}$ \\
cadiolide G (117) & 3.1 & 3.1 & 12.5 & 0.8 & 3.1 \\
cadiolide H (118) & 6.3 & 3.1 & 1.6 & 3.1 & 3.1 \\
cadiolide I (119) & 0.8 & 0.8 & 0.8 & 1.6 & 6.3 \\
cadiolide J (120) & 32 & $-\mathrm{b}$ & $-\mathrm{b}$ & 64 & 8 \\
cadiolide K (121) & 8 & $-\mathrm{b}$ & $-\mathrm{b}$ & 8 & 4 \\
cadiolide L (122) & 2 & $-\mathrm{b}$ & $-\mathrm{b}$ & 4 & 2 \\
cadiolide M (123) & 1 & $-\mathrm{b}$ & $-\mathrm{b}$ & $-\mathrm{b}$ & $-\mathrm{b}$ \\
cadiolide N (124) & 16 & $-\mathrm{b}$ & $-\mathrm{b}$ & 16 & 16 \\
\hline
\end{tabular}

${ }^{\text {a }}$ A: S. aureus; B: K. rhizophila; C: B. subtilis; D: S. enterica; E: Proteus hauseri;

$\mathrm{b}$ the symbol "-" means that the compound has not been tested yet.

Several metabolites originating from rearrangements and oxidization of the furanone core of rubrolides/cadiolides in different extents have been discovered. Synoilides A (125) and B (126) are two bis-aromatic esters related to rubrolides (Figure 13). These halogenated compounds are characterized 
by an unreported carbon skeleton that offered clear information of the structure-activity relationship for these metabolites endowed with a furanone and/or furanone-like portion [131]. Indeed, synoilides A and B exhibited only a weak antibacterial effect against B. subtilis and S. enterica (MICs of $50 \mu \mathrm{g} / \mathrm{mL}$ ) and, for this reason, the furanone ring appeared to be crucial for the bioactivity.<smiles>COC(=O)C(C(=O)OC)=C(C(=O)c1cc(Br)c(O)c(Br)c1)c1cc(Br)c(O)c(Br)c1</smiles>

synoilide $\mathrm{A}$ (125): $\mathrm{R}_{1}=-\mathrm{Br} ;(E / Z)$; synoilide $\mathrm{B}(\mathbf{1 2 6}): \mathrm{R}_{1}=-\mathrm{H} ;(E / Z)$;<smiles>[R]C1=C(c2cc([R])c(O)c(Br)c2)C(=O)C(c2cc(Br)c(O)c(Br)c2)(c2cc(Br)c(O)c(Br)c2)C1=O</smiles>

isocadiolide $\mathrm{A}$ (127): $\mathrm{R}_{1}=\mathrm{CO}_{2} \mathrm{CH}_{3} ; \mathrm{R}_{2}=\mathrm{R}_{3}=-\mathrm{Br}$; isocadiolide $\mathrm{B}(\mathbf{1 2 8}): \mathrm{R}_{1}=\mathrm{CO}_{2} \mathrm{CH}_{3} ; \mathrm{R}_{2}=\mathrm{R}_{3}=-\mathrm{H}$; isocadiolide $C$ (129): $R_{1}=H ; R_{2}=R_{3}=-B r$; isocadiolide $\mathrm{D}(\mathbf{1 3 0}): \mathrm{R}_{1}=\mathrm{CO}_{2} \mathrm{CH}_{3} ; \mathrm{R}_{2}=-\mathrm{Br} ; \mathrm{R}_{3}=-\mathrm{H}$; isocadiolide $\mathrm{E}(\mathbf{1 3 1}): \mathrm{R}_{1}=\mathrm{CO}_{2} \mathrm{H} ; \mathrm{R}_{2}=-\mathrm{H} ; \mathrm{R}_{3}=-\mathrm{Br}$;<smiles>[2H]C(=O)C1=C(c2cc(Br)c(O)c(Br)c2)[C@@](OC)(c2cc(Br)c(O)c(Br)c2)O[C@@]1(C(=O)OC)c1cc(Br)c(O)c(Br)c1</smiles>

isocadiolide $\mathrm{F}$ (132): $\mathrm{R}_{1}=-\mathrm{Br}$ isocadiolide $\mathrm{G}(\mathbf{1 3 3})$ : $\mathrm{R}_{1}=-\mathrm{H}$;

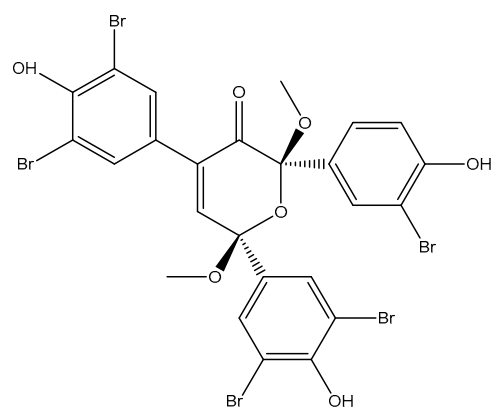

isocadiolide $\mathrm{H}(\mathbf{1 3 4})$

Figure 13. Structures of synoilides A (125) and B (126) and isocadiolides A-H (127-134).

Further studies of Synoicum sp. ascidian offshore of Keomun-do Island in Korea afforded the isolation of isocadiolides A-H (127-134), likely produced by rearrangements followed by oxidization of the furanone ring. These compounds are polybrominated aromatics that possess a tris-bromohydroxyphenil moiety linked to varied cores such as a cyclopentenedione, a dihydrofuran, or a pyranone ring (Figure 13) [135]. Chemical modification of the structural core determined a significant decrease of bioactivity; all isocadiolides exhibited a weaker activity than the relevant cadiolides. Among compounds 127-134, isocadiolide C (129) was the most potent against $S$. aureus, with an MIC of $4 \mu \mathrm{g} / \mathrm{mL}$, together with isocadiolides $\mathrm{A}, \mathrm{B}$, and D $(\mathbf{1 2 7}, \mathbf{1 2 8}, \mathbf{1 3 0} ; 16<\mathrm{MIC}(\mu \mathrm{g} / \mathrm{mL})<32)$; the Gram-positive E. faecalis was significantly compromised by isocadiolides G (133), which had $\mathrm{MIC}=8 \mu \mathrm{g} / \mathrm{mL}$, whereas isocadiolide B (128) possessed the same MIC against $P$. hauseri.

Although less potent than cadiolides, isocadiolides A-D (127-130) were effective in the inhibition of the transpeptidase sortase A of $S$. aureus, the enzyme involved in the virulence of Gram-positive bacteria $\left(\mathrm{IC}_{50}\right.$ in the range $\left.67-102 \mu \mathrm{M}\right)$ [136]. These results were particularly encouraging as the positive control used, berberine chloride, had an $\mathrm{IC}_{50}$ of $102 \mu \mathrm{M}$ [135]. Analogously, compounds 127-130 also showed similar values against the key enzyme isocitrate lyase of $C$. albicans, with $\mathrm{IC}_{50}$ of isocadiolide $\mathrm{A}$ $(22 \mu \mathrm{M})$, comparable to that of positive control 3-nitropropionate (17 $\mu \mathrm{M})$ [137]. 


\subsection{Exploring the Antimicrobial Properties of Metabolites from Ascidian-Associated Microorganisms}

A rich and filled community of microbes has been discovered to be associated with ascidians taking an active part in vital and metabolic functions of the marine invertebrates [23]. The impact of the natural products on the global health for the treatment of an array of diseases led to an extensive analysis of the biogenetic pathways, shedding light on their real producers. Hence, potent bioactive secondary metabolites, first considered to be synthesised by the ascidians, have later been further studied to assess their microbial origins, and thus the rich ascidian microbial diversity [138-140]. The well-known antitumor compound ecteinascidin 743 or the antineoplastic depsipeptide didemnin B, for example, are actually biosynthesised by ascidian-associated microorganisms, which have been defined as Candidatus Endoecteinascidia frumentensis, and Tistrella mobilis and T. bauzanensis, respectively [141,142]. Moreover, several studies have also demonstrated that the pairing ascidian-microorganism is species-selective $[24,138,143]$. Thus, in this last section of the present review, we describe several molecules isolated by ascidian-associated microorganisms and/or metabolites for which microorganisms have been established as their real producers.

\subsubsection{Ascidians-Associated Actinobacteria as Producers of Antimicrobial Compounds}

The actinobacteria Salinospora arenicola (CNR-647), associated with the ascidian Ecteinascidia turbinata, afforded arenimycin (135, Figure 14), a benzo[ $\alpha$ ] naphtacene quinone compound with significant antibiotic properties [144]. Arenimycin (135) exhibited a strong inhibition of bacterial growth with a MIC $<1 \mu \mathrm{g} / \mathrm{mL}$ against either multi-drug resistant Staphylococcus strains or E. faecalis and faecium. Moreover, arenimycin showed MIC $=1 \mu \mathrm{g} / \mathrm{mL}$ against the $M$. bacille, too. However, it was also active against human adenocarcinoma cell line (HCT-116) with $\mathrm{IC}_{50}=1.16 \mu \mathrm{g} / \mathrm{mL}$, thus these cytotoxic effects indicate a non-selective mechanism of action prevented further exploitation on this class of antibiotic compounds [144].

Another strain of actinobacteria of genus Salinospora, S. pacifica, was identified as the real producer of two diazotetrahydrobenzo[b]fluorene glycosides, lomaiviticins A and B (136 and 137, Figure 14) [145,146], isolated the ascidian P. lithostrotum. Initially, the two compounds were supposed to be produced by fermentation of a halophilic strain of the actinomycete Micronospora lomaivitiensis [145]. Subsequently, Janso and co-workers were able to identify the gene cluster of biosynthesis of compounds 136 and 137 by genome sequencing. This gene was related to S. pacifica strains DPJ-0016 and DPJ-0019, an actinobacteria with symbiotic association with the above-mentioned tunicate, too. Both compounds caused a potent DNA damage with a cleavage of the double stranded DNA, whereas lomaiviticin A (136) had a cytotoxicity profile comparable to DNA-damaging anticancer drugs, like adriamycin and mitomicin C. Alongside these effects, for two glycosides, the antibacterial activities were assessed. In particular, they were effective against S. aureus and E. faecium, with MICs ranging from 6 to $24 \mathrm{ng}$ per spot [145].

The marine Actinomadura sp. strains, associated with E. turbinata, were recognized as the producers of ecteinamycin (138, Figure 14) [147]. Ecteinamycin (138) showed an excellent selectivity for Clostridium difficile NAP1/B1/027 against that possessed an MIC of $59 \mathrm{ng} / \mu \mathrm{L}$. Further studies for its mechanism of action, based on chemical genomics, highlighted, for 138 , a high selectivity for $\mathrm{H}^{+} / \mathrm{K}^{+}$ ATPase disrupting vesicular trafficking, thus compromising the effects of Clostridium toxins [147].

The marine-derived Nocardia sp. has been demonstrated as a prolific source of secondary metabolites with various therapeutic applications including antibiotics [148]. The cultivation of Nocardia sp. WMMB215 strain, isolated from the ascidian Trididemnum orbiculatum, was found to produce several lipopeptides strictly correlated to the L-Val analogue of peptidolipin NA [149]. These compounds were correlated owing to a peptide cyclized via an ester to a lipophilic tail; some of these are discussed here seeing their antibacterial properties. The $80 \%$ mortality at 30 days of infection is caused by MRSA [150,151]. Hence, it is clearly necessary to discover new agents acting in this way. Focusing on this bioactivity, peptidolipins B (139) and E (140) from Nocardia sp. reported in Figure 14 are examples of compounds that inhibit methicillin-resistant S. aureus (MRSA) and methicillin-sensitive 
S. aureus (MSSA) strains. Interestingly, they showed a moderate antibacterial effect, considering an MIC of $64 \mu \mathrm{g} / \mathrm{mL}$ for both. Peptidolipins B and E were also investigated for the putative bacteriostatic, rather than bactericidal, mechanism of action. The wells, in which the bacterial growth was inhibited, were treated with a sterile swab and, as bacteria resumed to grow, $\mathbf{1 3 9}$ and $\mathbf{1 4 0}$ were deemed as bacteriostatic agents [149].
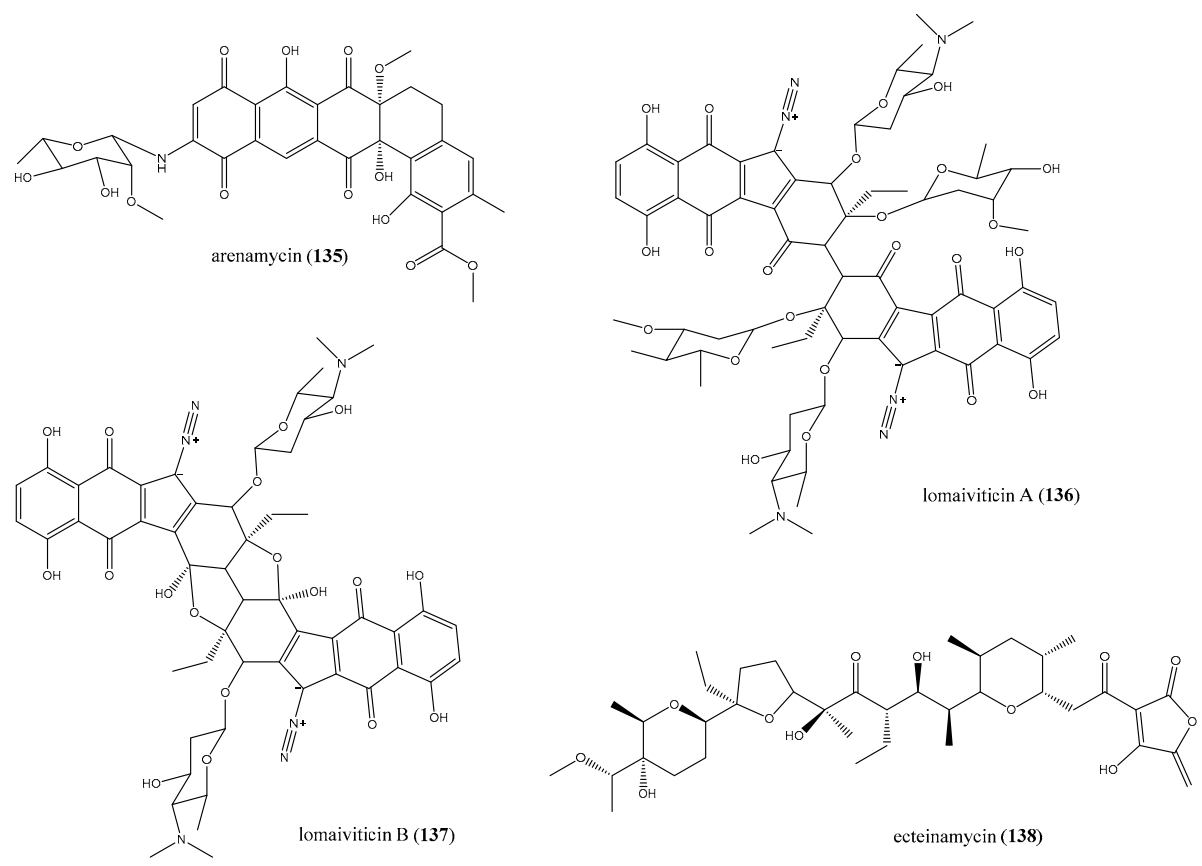

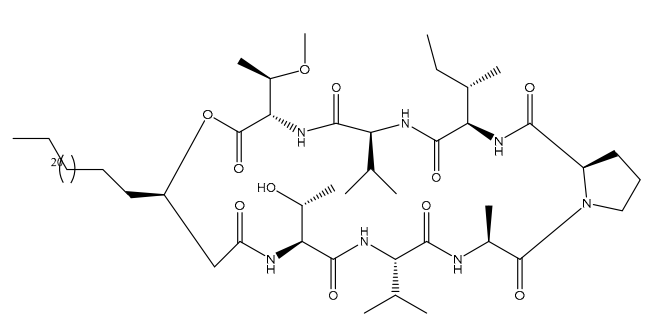

peptidolipin B (139)

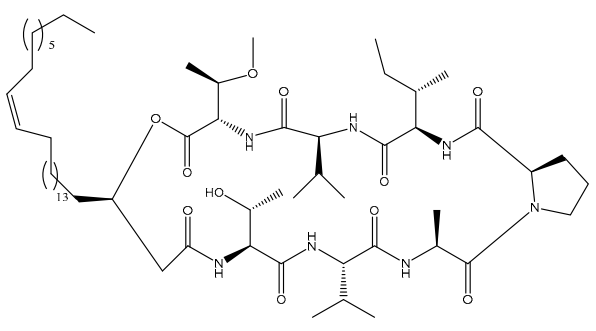

peptidolipin $\mathrm{E}(\mathbf{1 4 0})$
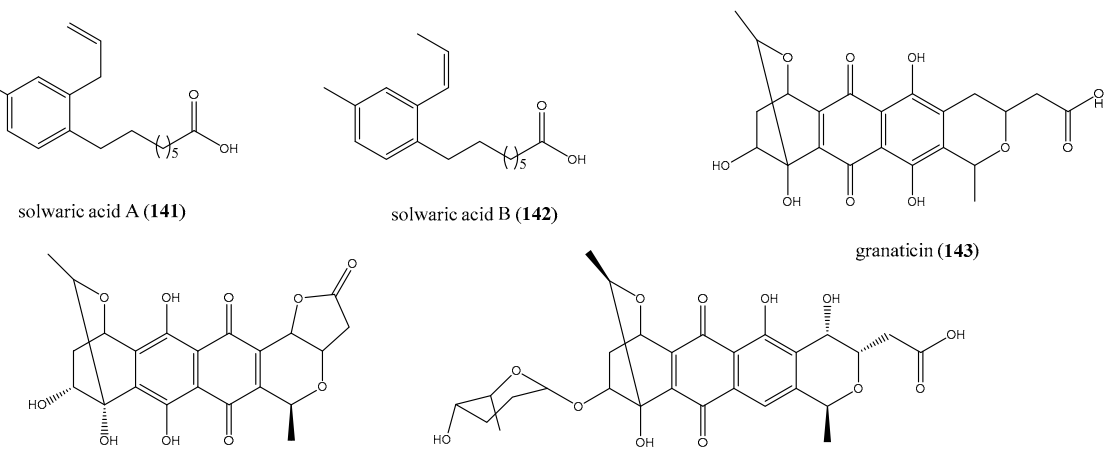

granatomycin $\mathrm{D}(\mathbf{1 4 4})$ granaticin (143)<smiles>CCCCCc1ccc(C)cc1CCC</smiles>

solwaric acid B (142)

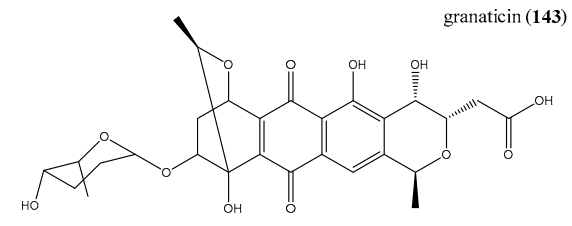

dihydrogranaticin $\mathrm{B}(\mathbf{1 4 5})$

Figure 14. Structures of compounds 135-145 derived from ascidian-associated actinobacteria.

Two trialkyl-substituted aromatic acids, solwaric acids A and B (141 and $\mathbf{1 4 2}$ reported in Figure 1), are further compounds isolated from an ascidian-associated microorganism, the actinobacteria 
Solwaraspora sp. [152]. This microbe such as Nocardia sp. was identified from T. orbiculatum and was the producer of metabolites such as 141 and 142. Both resulted in the inhibition of bacterial growth in vitro and, interestingly, were more potent against MRSA than MSSA strains, showing $\mathrm{MIC}=32 \mu \mathrm{g} / \mathrm{mL}$ against the methicillin resistant bacteria versus MIC $=64 \mu \mathrm{g} / \mathrm{mL}$ against MSSA [152]

Streptomyces spp. are a renowned reservoir of chemically diverse and biologically active metabolites, and have well adapted to living associated to marine ascidians $[148,153]$. The search of antimicrobial compounds from the solitary brown ascidian Styela canopus allowed the isolation of granaticin (143), granatomycin D (144), and dihydrogranaticin B (145), whose production was related to a strain of Streptomyces (PTY087I2) associated with the ascidian (Figure 14) [154]. Interestingly, the presence of compounds 143-145 in the co-cultures of PTY087I2 with MRSA strains enhanced the antibacterial efficacy; indeed, this co-culture was 16-, 4-, and 8-fold more active against B. subtilis, MSSA, and MRSA, respectively [154].

\subsubsection{The Role of Fungi in the Biosynthesis of Antimicrobial Compounds}

Fungi from marine environment are the second major class of ascidian-associated microorganisms, producers of secondary metabolites with an increased antimicrobial potential with respect to those derived from terrestrial fungi [155]. The production of several ascidian-derived bioactive compounds has been ascribed to Aspergillus sp., as demonstrated by the chemical analysis of marine fungal isolates from ascidians [156,157]. The symbiotic association between A. niger and the orange tunicate Aplidium sp. yielded a series of farnesylated epoxy cyclohexenones active against varied microorganism strains. The presence of quinone and quinone-derived moieties in marine metabolites is owing to the shikimic acid pathway supposed to be present in microbes and lacking in animals [158]. The Aplidium-associated Aspergillus was involved in the biosynthesis of yanuthones A-E (146-150), 1-hydroxyyanuthone A (151), 1-hydroxyyanuthone C (152), and 22-deacetylyanuthone A (153) (Figure 15). All compounds 146-153, except for yanuthones D and E (149 and 150), displayed only a slight inhibition of bacterial growth, with inhibition zones ranging from 8 to $10 \mathrm{~mm}$ against MSSA, MRSA, and vancomycin-resistant Enterococcus sp. when tested with the agar diffusion assay. Yanuthones D and E (149 and 150) were the most active compounds in the series, probably owing to the presence of a hydroxymethylglutaril (HMG) group at position 22, which increase the polarity of molecules, allowing a better agar diffusion and, definitely, a higher antibacterial effect. Yanuthone D showed zones of inhibition of $15 \mathrm{~mm}$ against either MSSA and vancomycin-resistant Enterococcus sp., while these zones for yanuthone E were of 13 and $12 \mathrm{~mm}$, respectively. Interestingly, both compounds were more potent against MRSA, exhibiting an inhibition zone of $17 \mathrm{~mm}$ at $62 \mu \mathrm{g}$ for $\mathbf{1 4 9}$ and $100 \mu \mathrm{g}$ for 150 [158].

Fuscoatrole A (154), the bicyclic sesterpene 11-epiterpestacin (155), and $\beta$-nitropropionic acid (156, Figure 15) were extracted from Humicola fuscoatra (KMM4629 strain), symbiont of undefined Kurial colonial ascidian [159]. Fuscoatrole A (154) is the first example of caryophyllenic sesquiterpene isolated from marine fungi, because caryophyllene type compounds are peculiar of terrestrial plants and fungi [160-162]. All three compounds 154-156 were effective against S. aureus and B. subtilis, with an $\mathrm{MIC}=12.5 \mu \mathrm{g} / \mathrm{mL}$ for fuscoatrole A, whereas 145 and 146 showed only a weak effect $(\mathrm{MIC}=100 \mu \mathrm{g} / \mathrm{mL})$. Therefore, $\beta$-nitropropionic acid (156) was also able to prevent both $C$. albicans and E. coli growth in vitro and its MIC value was calculated to be equal to $100 \mu \mathrm{g} / \mathrm{mL}$ [159].

Trichoderma virens is a species of ascomycete, and its association with many ascidians of genus Didemnum has been discovered. This fungi strain is noted for the production of the potent antibiotic gliotoxin, although it has been dismissed owing to its severe toxic effects in vivo [163]. The antibiotic trichodermamide B (157, Figure 15) was obtained from a culture of T. virens isolated from the ascidian D. molle collected along the cost of Papua New Guinea [164]. The X-ray diffraction permitted to define its structure that was characterized by the presence of a rare cyclic $O$-alkyl-oxime group into a six-membered ring. Compound 157 exhibited an MIC of $15 \mu \mathrm{g} / \mathrm{mL}$ against amphotericin-resistant strains of C. albicans, MRSA, and vancomycin-resistant strains of E. faecium, beyond a significant cytotoxic effect against HCT-116 cell line $\left(\mathrm{IC}_{50}=0.32 \mu \mathrm{g} / \mathrm{mL}\right)$. The bioactivity of trichodermamide $B$ 
(157) might be related to the chlorohydrin moiety, which could lead to an epoxide ring, which could represent its biologically active form [164].

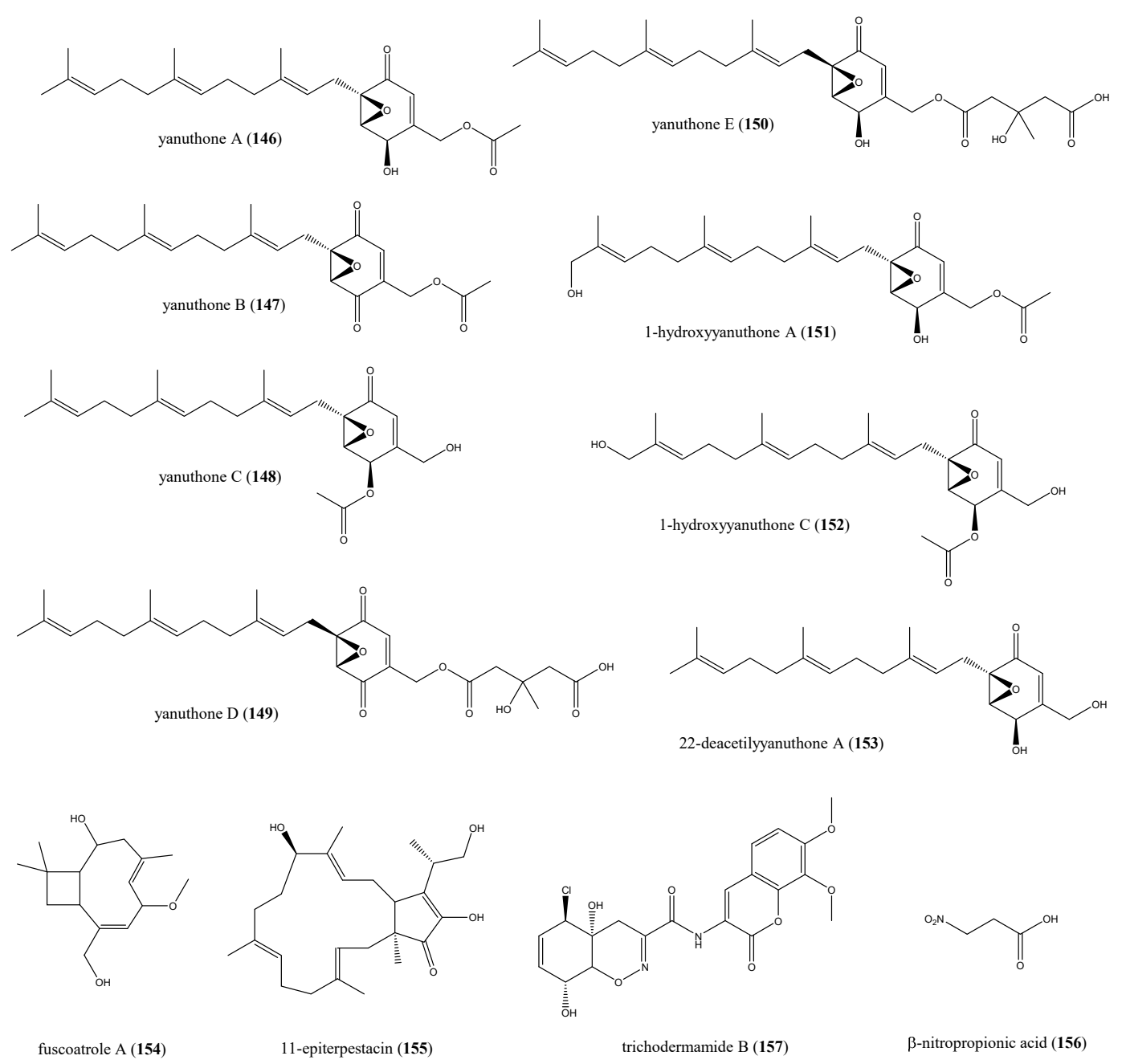

Figure 15. Structures of compounds 146-157 derived from ascidian-associated fungi.

\subsubsection{Bisanthraquinones from Cyanobacteria}

Nowadays, the role of cyanobacteria as producers of a wealth number of natural products is ever more emerging, helping to account for the symbiosis between microorganisms and marine invertebrates (Figure 1A) [137]. Cyanobacteria represent a class of photosynthetic Gram-negative bacteria also called blue-green algae, one of the oldest forms of life on Earth [165]. Harmful blooms of marine cyanobacteria are increasing as a consequence of human population growth as well as agricultural, urban and industrial activities. $[166,167]$. Nevertheless, cyanobacteria are producers of structurally diverse metabolites endowed with a broad spectrum of biological properties [168,169]. Bisanthrantaquinones 1 (158) and 2 (159) have been isolated from the blue-green algae strain (URI strain \# N36-11-10) identified from the colonial ascidian E. turbinate and are the known antibacterial metabolites from ascidian-associated cyanobacteria, up to now (Figure 16) [170]. Bisanthrantaquinone 1 (158) showed a greater antibacterial effectiveness than 2 (159); indeed, 158 exhibited MICs of 0.15 and $2.0 \mu \mathrm{M}$ against MRSA and vancomycin-resistant $E$. faecalis with respect to MICs of 0.36 and $12 \mu \mathrm{M}$ shown by 159, respectively. Bisanthraquinone 1 (158) was altogether 10-fold more active against MRSA than vancomycin-resistant strain of E. faecalis [170]. 


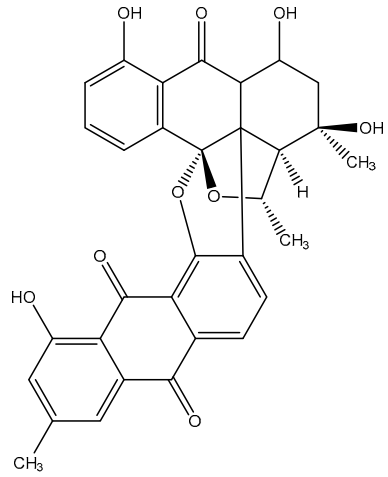

bisanthraquinone 1 (158)

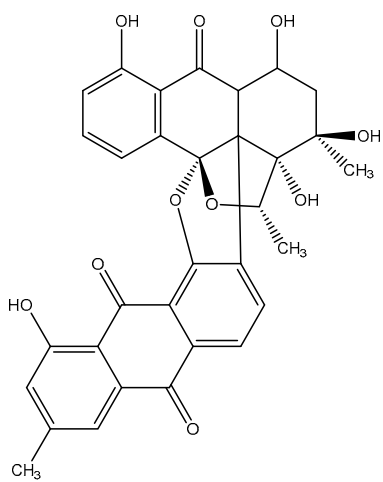

bisanthraquinone 2 (159)

Figure 16. Structures of the cyanobacteria-derived bisanthraquinones 1 and 2 (158 and 159).

\section{Conclusions}

The present review describes about 160 molecules endowed with antimicrobial activity produced by ascidians and/or by their associated microorganisms. The high and intrinsic chemiodiversity of ascidian substances is remarkable and strongly affords a chemical reservoir of peculiar scaffolds. This chemical and biological diversity represents a great opportunity to meet the urgent and increasing need of new antibiotic agents. The unique chemical class of ascidians antimicrobial metabolites, including sulfur-containing compounds, meroterpenes, alkaloids, peptides, furanones, and other aromatic derivatives, as well as their antimicrobial effects, undoubtedly could provide lead candidates for drug discovery programs in the anti-infective area of interest. The bioactivity of several metabolites is highly meaningful if compared with currently marketed drugs. Among these, lissoclinotoxin A (1) exhibits a very low MIC value $(0.08-0.15 \mu \mathrm{g} / \mathrm{mL})$ in the same range of the commercial cefatoxim against $S$. aureus. Analogously, namenamicin (7), the only enediyne natural product of marine origin, was a potent antibiotic, even more active than penicillin $\mathrm{G}$ against a wide panel of bacteria and fungi (MICs ranging 0.004-0.25 $\mu \mathrm{g} / \mathrm{mL}$ ). Furthermore, the strong antifungal potency against $C$. albicans (MIC $=0.7 \pm 0.05 \mu \mathrm{g} / \mathrm{mL}$ ) and the moderate effect against $C$. glabrata $(\mathrm{MIC}=30.0 \mu \mathrm{g} / \mathrm{mL}$ ) allow to consider the (2S, 3R)-2-aminododecan-3-ol (34) to be comparable to clinically used antifungal agents, such as nystatin and ketoconazole. Interestingly, the antibacterial efficacy of rubrolide A (97) and J (109) was comparable or even better than two antibiotic marketed-drugs, linezolid and platensimycin, against MSSA and MRSA strains. Therefore, although the ascidian's secondary metabolites have been highlighted as an extraordinary arsenal of novel drug lead structures, the studies have often been limited to the knowledge of the biological effects in vitro. Very few attempts, not to say none, have been made to deepen the pharmacological characterization of these molecules, for example, by investigating the mode of action of the active metabolites; in some cases, simple structure activity relationships (SARs) have been tentatively proposed. This fact, if on the one hand can be considered a disadvantage, on the other shows us, in perspective, a still virgin and practically unexplored field of exploration of new structures and new mechanisms, which could play an important role in the future in the fight against the global infectious-disease burden and the resistance issue.

Author Contributions: Conceptualization, M.C., M.M., and C.I.; methodology, M.C.; software, M.C.; validation, M.M. and C.I.; formal analysis, M.C., M.M., and C.I.; investigation, M.C. and C.I., resources, C.I.; data curation, M.C., M.M., and C.I.; writing—original draft preparation, M.C., M.M., and C.I.; writing—review and editing, M.C., M.M., and C.I.; visualization, M.C., M.M., and C.I.; supervision, M.M.; funding acquisition, M.M. All authors have read and agreed to the published version of the manuscript.

Funding: This research was funded by a grant from Regione Campania-POR Campania FESR 2014/2020 "Combattere la resistenza tumorale: piattaforma integrata multidisciplinare per un approccio tecnologico innovativo alle oncoterapie-Campania Oncoterapie" (Project N. B61G18000470007).

Conflicts of Interest: The authors declare no conflict of interest. 


\section{References}

1. Furusawa, C.; Horinouchi, T.; Maeda, T. Toward Prediction and Control of Antibiotic-Resistance Evolution. Curr. Opin. Biotechnol. 2018, 54, 45-49. [CrossRef]

2. WHO. No Time to Wait: Securing the Future from Drug-Resistant Infections. April 2019. Available online: https://www.who.int/antimicrobial-resistance/interagency-coordination-group/final-report/en/ (accessed on 30 April 2019).

3. Silva, O.N.; de La Fuente-Núñez, C.; Haney, E.F.; Fensterseifer, I.C.; Ribeiro, S.M.; Porto, W.F.; Brown, P.; Faria-Junior, C.; Rezende, T.M.; Moreno, S.E.; et al. An Anti-Infective Synthetic Peptide with Dual Antimicrobial and Immunomodulatory Activities. Sci. Rep. 2016, 6, 35465. [CrossRef]

4. Rosén, J.; Gottfries, J.; Muresan, S.; Backlund, A.; Oprea, T.I. Novel Chemical Space Exploration via Natural Products. J. Med. Chem. 2009, 52, 1953-1962.

5. Millero, F.J. Descriptive Oceanography. In Chemical Oceanography, 4th ed.; CRC Press Taylor \& Francis Group: Boca Raton, FL, USA, 2013.

6. Newman, D.J.; Cragg, G.M. Marine Natural Products and Related Compounds in Clinical and Advanced Preclinical Trials. J. Nat. Prod. 2004, 67, 1216-1238. [CrossRef]

7. Panno, L.; Bruno, M.; Voyron, S.; Anastasi, A.; Gnavi, G.; Miserere, L.; Varese, G.C. Diversity, Ecological Role and Potential Biotechnological Applications of Marine Fungi Associated to the Seagrass Posidonia Oceanica. New Biotechnol. 2013, 30, 685-694. [CrossRef]

8. Liang, X.; Luo, D.; Luesch, H. Advances in Exploring the Therapeutic Potential of Marine Natural Products. Pharmacol. Res. 2019, 147, 104373-104391. [CrossRef]

9. Hu, Y.; Chen, J.; Hu, G.; Yu, J.; Zhu, X.; Lin, Y.; Chen, S.; Yuan, J. Statistical Research on the Bioactivity of New Marine Natural Products Discovered during the 28 Years from 1985 to 2012. Mar. Drugs 2015, 13, 202-221. [CrossRef]

10. Carroll, A.R.; Copp, B.R.; Davis, R.A.; Keyzers, R.A.; Prinsep, M.R. Marine Natural Products. Nat. Prod. Rep. 2019, 36, 122-173. [CrossRef]

11. Carroll, A.R.; Copp, B.R.; Davis, R.A.; Keyzers, R.A.; Prinsep, M.R. Marine Natural Products. Nat. Prod. Rep. 2020, 37, 175-223. [CrossRef]

12. Menna, M.; Aiello, A.; D’Aniello, F.; Fattorusso, E.; Imperatore, C.; Luciano, P.; Vitalone, R. Further Investigation of the Mediterranean Sponge Axinella polypoides: Isolation of a New Cyclonucleoside and a New Betaine. Mar. Drugs 2012, 10, 2509-2518. [CrossRef]

13. Imperatore, C.; D'Aniello, F.; Aiello, A.; Fiorucci, S.; D’Amore, C.; Sepe, V.; Menna, M. Phallusiasterols A and B: Two New Sulfated Sterols from the Mediterranean Tunicate Phallusia fumigata and Their Effects as Modulators of the PXR Receptor. Mar. Drugs 2014, 12, 2066-2078. [CrossRef] [PubMed]

14. Aiello, A.; Fattorusso, E.; Imperatore, C.; Luciano, P.; Menna, M.; Vitalone, R. Aplisulfamines, New Sulfoxide-Containing Metabolites from an Aplidium Tunicate: Absolute Stereochemistry at Chiral Sulfur and Carbon Atoms Assigned through an Original Combination of Spectroscopic and Computational Methods. Mar. Drugs 2012, 10, 51-63. [CrossRef] [PubMed]

15. Newman, D.J.; Cragg, G.M. Natural Products as Sources of New Drugs from 1981 to 2014. J. Nat. Prod. 2016, 79, 629-661. [CrossRef] [PubMed]

16. Imperatore, C.; Luciano, P.; Aiello, A.; Vitalone, R.; Irace, C.; Santamaria, R.; Li, J.; Guo, Y.; Menna, M. Structure and Configuration of Phosphoeleganin, a Protein Tyrosine Phosphatase 1B Inhibitor from the Mediterranean Ascidian Sidnyum elegans. J. Nat. Prod. 2016, 79, 1144-1148. [CrossRef]

17. Luciano, P.; Imperatore, C.; Senese, M.; Aiello, A.; Casertano, M.; Guo, Y.; Menna, M. Assignment of the Absolute Configuration of Phosphoeleganin via Synthesis of Model Compounds. J. Nat. Prod. 2017, 80, 2118-2123. [CrossRef]

18. Lars, S.; Kjeldsen, K.U.; Funch, P.; Jensen, J.; Obst, M.; López-Legentil, S.; Schramm, A. Endozoicomonas Are Specific, Facultative Symbionts of Sea Squirts. Front. Microbiol. 2016, 7, 1042.

19. Shenkar, N.; Swalla, B.J. Global Diversity of Ascidiacea. PLoS ONE 2011, 6, E20657. [CrossRef]

20. Rangel, M.; Falkenberg, M. An Overview of the Marine Natural Products in Clinical Trials and on the Market. J. Coast. Life Med. 2015, 3, 421-428.

21. Palanisamy, S.K.; Rajendran, N.M.; Marino, A. Natural Products Diversity of Marine Ascidians (Tunicates; Ascidiacea) and Successful Drugs in Clinical Development. Nat. Prod. Bioprospect. 2017, 7, 1-111. [CrossRef] 
22. Pereira, F. Have Marine Natural Product Drug Discovery Efforts Been Productive and How Can We Improve Their Efficiency? Expert Opin. Drug Dis. 2019, 14, 717-722. [CrossRef]

23. Chen, L.; Hu, J.-S.; Xu, J.-L.; Shao, C.-L.; Wang, G.-Y. Biological and Chemical Diversity of Ascidian-Associated Microorganisms. Mar. Drugs 2018, 16, 362. [CrossRef]

24. Schmidt, E.W. The Secret to a Successful Relationship: Lasting Chemistry between Ascidians and Their Symbiotic Bacteria. Invertebr. Biol. 2014, 134, 88-102. [CrossRef]

25. Davison, E.K.; Sperry, J. Natural Products with Heteroatom-Rich Ring Systems. J. Nat. Prod. 2017, 80, 3060-3079. [CrossRef]

26. Casertano, M.; Imperatore, C.; Luciano, P.; Aiello, A.; Putra, M.Y.; Gimmelli, R.; Ruberti, G.; Menna, M. Chemical Investigation of the Indonesian Tunicate Polycarpa aurata and Evaluation of the Effects Against Schistosoma mansoni of the Novel Alkaloids Polyaurines A and B. Mar. Drugs 2019, 17, 278. [CrossRef]

27. Zabriskie, T.M.; Mayne, C.L.; Ireland, C.M. Patellazole C: A Novel Cytotoxic Macrolide from Lissoclinum patella. J. Am. Chem. Soc. 1988, 110, 7919-7920. [CrossRef]

28. Davidson, B.S.; Ireland, C.M. Lissoclinolide, the First Non-Nitrogenous Metabolite from a Lissoclinum Tunicate. J. Nat. Prod. 1990, 53, 1036-1038. [CrossRef]

29. Litaudon, M.; Guyot, M. Lissoclinotoxin A, an Antibiotic 1,2,3-Trithiane Derivative from the Tunicate Lissoclinum perforatum. Tetrahedron Lett. 1991, 32, 911-914. [CrossRef]

30. Litaudon, M.; Trigalo, F.; Martin, M.T.; Frappier, F.; Guyot, M. Lissoclinotoxins: Antibiotic Polysulfur Derivatives From The Tunicate Lissodinum perforatum. Revised Structure of Lissoclinotoxin A. Tetrahedron 1994, 50, 5323-5334. [CrossRef]

31. Davidson, B.S.; Molinski, T.F.; Barrows, L.R.; Ireland, C.M. Varacin: A Novel Benzopentathiepin from Lissoclinum vareau That Is Cytotoxic toward a Human Colon Tumor. J. Am. Chem. Soc. 1991, 113, 4709. [CrossRef]

32. Makarieva, T.N.; Stonik, V.A.; Dmitrenok, A.S.; Grebnev, B.B.; Isakov, V.V.; Rebachyk, N.M. Varacin and Three Marine Antimicrobial Polysulfides from the Far-Eastern Ascidian Polycitor Sp. J. Nat. Prod. 1995, 58, 254-258. [CrossRef]

33. McDonald, L.A.; Capson, T.L.; Krishnamurthy, G.; Ding, W.D.; Ellestad, G.A.; Bernan, V.S.; Maiese, W.M.; Lassota, P.; Discafani, C.; Kramer, R.A.; et al. Namenamicin, a New Enediyne Antitumor Antibiotic from the Marine Ascidian Polysyncraton lithostrotum. J. Am. Chem. Soc. 1996, 118, 10898-10899. [CrossRef]

34. Aiello, A.; Fattorusso, E.; Menna, M.; Carnuccio, R.; Iuvone, T. A New Antiproliferative Sulfated Alkene from the Mediterranean Tunicate Microcosmus vulgaris. Tetrahedron 1997, 53, 11489-11492. [CrossRef]

35. Aiello, A.; Carbonelli, S.; Fattorusso, E.; Iuvone, T.; Menna, M. New Bioactive Sulfated Metabolites from the Mediterranean Tunicate Sydnium turbinatum. J. Nat. Prod. 2001, 64, 219-221. [CrossRef]

36. Tsukamoto, S.; Kato, H.; Hirota, H.; Fusetani, N. Antibacterial and Antifungal Sulfated Alkane and Alkanes from the Hepatopancreas of the Ascidian Halocynthia Roretzi. J. Nat. Prod. 1994, 57, 1606-1609. [CrossRef]

37. Menna, M.; Imperatore, C.; D'Aniello, F.; Aiello, A. Meroterpenes from Marine Invertebrates: Structures, Occurrence, and Ecological Implications. Mar. Drugs 2013, 11, 1602-1643. [CrossRef]

38. Simon-Levert, A.; Menniti, C.; Soulère, L.; Genevière, A.; Barthomeuf, C.; Banaigs, B.; Witczak, A. Marine Natural Meroterpenes: Synthesis and Antiproliferative Activity. Mar. Drugs 2010, 8, 347-358. [CrossRef]

39. Zubia, E.; Ortega, M.J.; Salva, J. Natural Products Chemistry in Marine Ascidians of the Genus Aplidium. Mini-Rev. Org. Chem. 2005, 2, 389-399.

40. Imperatore, C.; Persico, M.; Aiello, A.; Luciano, P.; Guiso, M.; Sanasi, M.F.; Taramelli, D.; Parapini, S.; Cebrián-Torrejón, G.; Doménech-Carbó, A.; et al. Marine Inspired Antiplasmodial Thiazinoquinones: Synthesis, Computational Studies and Electrochemical Assays. RSC Adv. 2015, 5, 70689-70702. [CrossRef]

41. Imperatore, C.; Gimmelli, R.; Persico, M.; Casertano, M.; Guidi, A.; Saccoccia, F.; Ruberti, G.; Luciano, P.; Aiello, A.; Parapini, S.; et al. Investigating the Antiparasitic Potential of the Marine Sesquiterpene Avarone, Its Reduced Form Avarol, and the Novel Semisynthetic Thiazinoquinone Analogue Thiazoavarone. Mar. Drugs 2020, 18, 112. [CrossRef]

42. Imperatore, C.; Della Sala, G.; Casertano, M.; Luciano, P.; Aiello, A.; Laurenzana, I.; Piccoli, P.; Menna, M. In Vitro Antiproliferative Evaluation of Synthetic Meroterpenes Inspired by Marine Natural Products. Mar. Drugs 2019, 17, 684. [CrossRef] 
43. Fedorov, S.N.; Radchenko, O.S.; Shubina, L.K.; Balaneva, N.N.; Bode, A.M.; Stonik, V.A.; Dong, Z. Evaluation of Cancer-Preventive Activity and Structure-Activity Relationships of 3-Demethylubiquinone Q2, Isolated from the Ascidian Aplidium Glabrum, and Its Synthetic Analogs. Pharm. Res. 2006, 23, 70-81. [CrossRef] [PubMed]

44. Caroll, A.R.; Bowden, B.F.; Coll, J.C. Studies of Australian Ascidians. III. A New Tetrahydrocannabinol Derivative from the Ascidian Synoicum Castellatum. Aust. J. Chem. 1993, 46, 1079-1083. [CrossRef]

45. Garrido, L.; Zubia, E.; Ortega, M.J.; Salva, J. New Meroterpenoids from the Ascidian Aplidium Conicum. J. Nat. Prod. 2002, 65, 1328-1331. [CrossRef] [PubMed]

46. Simon-Levert, A.; Arrault, A.; Bontemps-Subielos, N.; Canal, C.; Banaigs, B. Meroterpenes from the Ascidian Aplidium Densum. J. Nat. Prod. 2005, 68, 1412-1415. [CrossRef]

47. Benslimane, A.F.; Pouchus, Y.F.; Le Boterff, J.; Verbist, J.F.; Roussakis, C.; Monniot, F. Cytotoxic and Antibacterial Substances from the Ascidian Aplidium Antillense. J. Nat. Prod. 1988, 51, 582-583. [CrossRef]

48. Appleton, D.R.; Chuen, C.S.; Berridge, M.V.; Webb, V.L.; Copp, B.R. Rossinones A and B, Biologically Active Meroterpenoids from the Antarctic Ascidian, Aplidium Species. J. Org. Chem. 2009, 74, 9195-9198. [CrossRef]

49. Carbone, M.; Núñez-Pons, L.; Castelluccio, F.; Avila, C.; Gavagnin, M. New Meroterpenoids from the Antarctic Ascidian Aplidium Fuegiense. Tetrahedron 2012, 68, 3541-3544. [CrossRef]

50. Núñez-Pons, L.; Carbone, M.; Vázquez, J.; Rodríguez, J.; Nieto, R.M.; Varela, M.M.; Gavagnin, M.; Avila, C. Natural Products from Antarctic Colonial Ascidians of the Genera Aplidium and Synoicum: Variability and Defensive Role. Mar. Drugs 2012, 10, 1741-1764. [CrossRef]

51. Ciavatta, M.L.; Manzo, E.; Nuzzo, G.; Villani, G.; Varcamonti, M.; Gavagnin, M. Crucigasterins A-E, Antimicrobial Amino Alcohols from the Mediterranean Colonial Ascidian Pseudodistoma crucigaster. Tetrahedron 2010, 66, 7533-7538. [CrossRef]

52. Jares-Erijman, E.A.; Bapat, C.P.; Lithgow-Bertelloni, A.; Rinehart, K.L.; Sakai, R. Crucigasterins, New Polyunsaturated Amino Alcohols from the Mediterranean Tunicate Pseudodistoma Crucigaster. J. Org. Chem. 1993, 58, 5732-5737. [CrossRef]

53. Gulavita, N.K.; Scheuer, P.J. Two Epimeric Aliphatic Amino Alcohols from a Sponge, Xestospongia Sp. J. Org. Chem. 1989, 54, 366-369. [CrossRef]

54. Kobayashi, J.; Naitoh, K.; Doi, Y.; Ishibashi, M. Pseudodistomin C, a New Piperidine Alkaloid with Unusual Absolute Configuration from the Okinawan Tunicate Pseudodistoma Kanoko. J. Org. Chem. 1995, 60, 6941-6945. [CrossRef]

55. Won, T.H.; You, M.; Lee, S.H.; Rho, B.J.; Oh, D.C.; Oh, K.B.; Shin, J. Amino Alcohols from the Ascidian Pseudodistoma Sp. Mar. Drugs 2014, 12, 3754-3769. [CrossRef] [PubMed]

56. Kossuga, M.H.; MacMillan, J.B.; Rogers, E.W.; Molinski, T.F.; Nascimento, G.G.F.; Rocha, R.M.; Berlinck, R.G.S. (2S,3R)-2-Aminododecan-3-Ol, a New Antifungal Agent from the Ascidian Clavelina Oblonga. J. Nat. Prod. 2004, 67, 1879-1881. [CrossRef]

57. Wang, J.; Pearce, A.N.; Chan, S.T.S.; Taylor, R.B.; Page, M.J.; Valentin, A.; Bourguet-Kondracki, M.L.; Dalton, J.P.; Wiles, S.; Copp, B.R. Biologically Active Acetylenic Amino Alcohol and N-Hydroxylated 1,2,3,4-Tetrahydro- $\beta$-Carboline Constituents of the New Zealand Ascidian Pseudodistoma Opacum. J. Nat. Prod. 2016, 79, 607-610.

58. Perron, F.; Albizati, K.F. Chemistry of Spiroketals. Chem. Rev. 1989, 89, 1617-1661. [CrossRef]

59. Aho, J.E.; Pihko, P.M.; Rissa, T.K. Nonanomeric Spiroketals in Natural Products: Structures, Sources, and Synthetic Strategies. Chem. Rev. 2005, 105, 4406-4440. [CrossRef]

60. Sperry, J.; Wilson, Z.E.; Rathwell, D.C.K.; Brimble, M.A. Isolation, Biological Activity and Synthesis of Benzannulated Spiroketalnatural Products. Nat. Prod. Rep. 2010, 27, 1117-1137. [CrossRef]

61. Zang, F.M.; Zhang, S.Y.; Tu, Y.Q. Recent Progress in the Isolation, Bioactivity, Biosynthesis, and Total Synthesis of Natural Spiroketals. Nat. Prod. Rep. 2018, 35, 75-104. [CrossRef]

62. Pika, J.; Faulkner, D.J. A Reinvestigation of the Didemnaketals from the Palauan Ascidian Didemnum Sp. Nat. Prod. Lett. 1995, 7, 291-296. [CrossRef]

63. Potts, B.C.M.; Faulkner, D.J. Didemnaketals A and B, HIV-1 Protease Inhibitors from the Ascidian Didemnum Sp. J. Am. Chem. Soc. 1991, 113, 6321-6322. [CrossRef]

64. Mohamed, G.A.; Ibrahim, S.R.M.; Badr, J.M.; Youssef, D.T.A. Didemnaketals D and E, Bioactive Terpenoids from a Red Sea Ascidian Didemnum Species. Tetrahedron 2014, 70, 35-40. [CrossRef] 
65. Shaala, L.A.; Youssef, D.T.A.; Ibrahim, S.R.M.; Mohamed, G.A.; Badr, J.M.; Risinger, A.L.; Mooberry, S.L. Didemnaketals F and G, New Bioactive Spiroketals from a Red Sea Ascidian Didemnum Species. Mar. Drugs 2014, 12, 5021-5034. [CrossRef] [PubMed]

66. Cheung, R.C.; Ng, T.B.; Wong, J.H. Marine Peptides: Bioactivities and Applications. Mar. Drugs 2015, 13, 4006-4043. [CrossRef] [PubMed]

67. Kang, H.K.; Seo, C.H.; Park, Y. Marine Peptides and Their Anti-Infective Activities. Mar. Drugs 2015, 13, 618-654. [CrossRef]

68. Falanga, A.; Lombardi, L.; Franci, G.; Vitiello, M.; Iovene, M.R.; Morelli, G.; Galdiero, M.; Galdiero, S. Marine Antimicrobial Peptides: Nature Provides Templates for the Design of Novel Compounds against Pathogenic Bacteria. Int. J. Mol. Sci. 2016, 17, 785. [CrossRef]

69. Cruz, J.; Ortiz, C.; Guzman, F.; Fernandez-Lafuente, R.; Torres, R. Antimicrobial Peptides: Promising Compounds against Pathogenic Microorganisms. Curr. Med. Chem. 2014, 21, 2299-2321. [CrossRef]

70. Hurdle, J.G.; O’Neill, A.J.; Chopra, I.; Lee, R.E. Targeting Bacterial Membrane Function: An Underexploited Mechanism for Treating Persistent Infections. Nat. Rev. Microbiol. 2011, 9, 62-75. [CrossRef]

71. Lehrer, R.I.; Tincu, J.A.; Taylor, S.W.; Menzel, L.P.; Waring, A.J. Natural Peptide Antibiotics from Tunicates: Structures, Functions and Potential Uses. Integr. Comp. Biol. 2003, 43, 313-322. [CrossRef]

72. Lee, I.H.; Cho, Y.; Lehrer, R.I. Styelins, Broad-Spectrum Antimicrobial Peptides from the Solitary Tunicate, Styela Clava. Comp. Biochem. Physiol. 1997, 118B, 515-521. [CrossRef]

73. Taylor, S.W.; Craig, A.G.; Fischer, W.H.; Park, M.; Lehrer, R.I. Styelin D, an Extensively Modified Antimicrobial Peptide from Ascidian Hemocytes. J. Biol. Chem. 2000, 275, 38417-38426. [CrossRef] [PubMed]

74. Lee, I.H.; Zhao, C.; Cho, Y.; Harwig, S.S.L.; Cooper, E.L.; Lehrer, R.I. Clavanins, $\alpha$-Helical Antimicrobial Peptides from Tunicate Hemocytes. FEBS Lett. 1997, 400, 158-162. [CrossRef]

75. Saude, A.C.; Ombredane, A.S.; Silva, O.N.; Barbosa, J.A.; Moreno, S.E.; Guerra Araujo, A.C.; Falcão, R.; Silva, L.P.; Dias, S.C.; Franco, O.L. Clavanin Bacterial Sepsis Control Using a Novel Methacrylate Nanocarrier. Int. J. Nanomed. 2014, 9, 5055-5069.

76. Galinier, R.; Roger, E.; Sautiere, P.E.; Aumelas, A.; Banaigs, B.; Mitta, G. Halocyntin and Papillosin, Two New Antimicrobial Peptides Isolated from Hemocytes of the Solitary Tunicate, Halocynthia Papillosa. J. Pept. Sci. 2009, 15, 48-55. [CrossRef]

77. Lee, I.H.; Lee, Y.S.; Kim, C.H.; Kim, C.R.; Hong, T.; Menzel, L.; Boo, L.M.; Pohl, J.; Sherman, M.A.; Waring, A.; et al. Dicynthaurin: An Antimicrobial Peptide from Hemocytes of the Solitary Tunicate, Halocynthia Aurantium. Biochim. Biophys. Acta 2001, 1527, 141-148. [CrossRef]

78. Jang, W.S.; Kim, K.N.; Lee, Y.S.; Nam, M.H.; Lee, I.H. Halocidin: A New Antimicrobial Peptide from Hemocytes of the Solitary Tunicate, Halocynthia Aurantium. FEBS Lett. 2002, 521, 81-86. [CrossRef]

79. Jang, W.S.; Kim, H.K.; Lee, K.Y.; Kim, S.A.; Han, Y.S.; Lee, I.H. Antifungal Activity of Synthetic Peptide Derived from Halocidin, Antimicrobial Peptide from the Tunicate, Halocynthia Aurantium. FEBS Lett. 2006, 580, 1490-1496. [CrossRef]

80. Jang, W.S.; Kim, C.H.; Kang, M.S.; Chae, H.J.; Son, S.M.; Seo, S.J.; Lee, I.H. CDNA Cloning of Halocidin and a New Antimicrobial Peptide Derived from the N-Terminus of Ci-META4. Peptides 2005, 26, 2360-2367. [CrossRef]

81. Hansen, I.K.Ø.; Isaksson, J.; Poth, A.G.; Hansen, K.Ø.; Andersen, A.J.C.; Richard, C.S.M.; Blencke, H.-M.; Stensvåg, K.; Craik, D.J.; Haug, T. Isolation and Characterization of Antimicrobial Peptides with Unusual Disulfide Connectivity from the Colonial Ascidian Synoicum Turgens. Mar. Drugs 2020, 18, 51. [CrossRef]

82. Oltz, E.M.; Bruening, R.C.; Smith, M.J.; Kustin, K.; Naganishi, K. The Tunichromes. A Class of Reducing Blood Pigments from Sea Squirts: Isolation, Structures, and Vanadium Chemistry. J. Am. Chem. Soc. 1988, 110, 6162-6172. [CrossRef]

83. Azumi, K.; Yokosawa, H.; Ishii, S. Halocyamines: Novel Antimicrobial Tetrapeptide-like Substances Isolated from the Hemocytes of the Solitary Ascidian Halocynthia Roretzi. Biochemistry 1990, 29, 159-165. [CrossRef] [PubMed]

84. Azumi, K.; Yokosawa, H.; Ishii, S. Presence of 3,4-Dihydroxyphenylalanine-Containing Peptides in Hemocytes of the Ascidian, Halocynthia Roretzi. Experientia 1990, 46, 1020-1023. [CrossRef]

85. Azumi, K.; Yoshimizu, M.; Suzuki, S.; Ezura, Y.; Yokosawa, H. Inhibitory Effect of Halocyamine, an Antimicrobial Substance from Ascidian Hemocytes, on the Growth of Fish Viruses and Marine Bacteria. Experientia 1990, 46, 1066-1068. [CrossRef] [PubMed] 
86. Kossuga, M.H.; Lira, P.A.; McHugh, S.; Torres, Y.R.; Lima, B.A.; Gonçalves, R.; Veloso, K.; Ferreira, A.G.; Rocha, R.M.; Berlinck, R.G.S. Antibacterial Modified Diketopiperazines from Two Ascidians of the Genus Didemnum. J. Braz. Chem. Soc. 2009, 20, 704-711. [CrossRef]

87. Lima, B.D.A.; de Lira, S.P.; Kossuga, M.H.; Gonçalves, R.B.; Berlinck, R.G.S.; Kamiya, R.U. Halistanol Sulfate A and Rodriguesines A and B Are Antimicrobial and Antibiofilm Agents against the Cariogenic Bacterium Streptococcus Mutans. Rev. Bras. Farmacogn. 2014, 24, 651-659. [CrossRef]

88. Menna, M.; Fattorusso, E.; Imperatore, C. Alkaloids from Marine Ascidians. Molecules 2011, 16, 8694-8732. [CrossRef]

89. Choudhary, A.; Naughton, L.M.; Montánchez, I.; Dobson, A.D.W.; Rai, D.K. Current Status and Future Prospects of Marine Natural Products (MNPs) as Antimicrobials. Mar. Drugs 2017, 15, 272. [CrossRef]

90. Imperatore, C.; Valadan, M.; Tartaglione, L.; Persico, M.; Ramunno, A.; Menna, M.; Casertano, M.; Dell'Aversano, C.; Singh, M.; d'Aulisio Garigliota, M.L.; et al. Exploring the Photodynamic Properties of Two Antiproliferative Benzodiazopyrrole Derivatives. Int. J. Mol. Sci. 2020, 21, 1246. [CrossRef]

91. Wang, W.; Nam, S.-J.; Lee, B.-C.; Kang, H. b-Carboline Alkaloids from a Korean Tunicate Eudistoma Sp. J. Nat. Prod. 2008, 71, 163-166. [CrossRef]

92. Schumacher, R.W.; Davidson, B.S. Didemnolines A-D, New N9-Substituted b-Carbolines from the Marine Ascidian Didemnum Sp. Tetrahedron 1995, 51, 10125-10130. [CrossRef]

93. Wona, T.H.; Jeon, J.; Lee, S.H.; Rho, B.J.; Oh, K.B.; Shin, J. Beta-Carboline Alkaloids Derived from the Ascidian Synoicum Sp. Bioorg. Med. Chem. 2012, 20, 4082-4087. [CrossRef] [PubMed]

94. Kobayashi, J.; Harbour, G.C.; Gilmore, J.; Rinehart, K.L., Jr. Eudistomins A, D, G, H, I, J, M, N, 0, P, and Q, Bromo-, Hydroxy-, Pyrrolyl-, and 1-Pyrrolinyl-P-Carbolines from the Antiviral Caribbean Tunicate Eudistoma Olivaceum. J. Am. Chem. Soc. 1984, 106, 1526-1528. [CrossRef]

95. Rinehart, K.L., Jr.; Kobayashi, J.; Harbour, G.C.; Highes, R.G.; Mizsak, S.A.; Scahill, T.A. Eudistomins C, E, K, and L, Potent Antiviral Compounds Containing a Novel Oxathiazepine Ring from the Caribbean Tunicate Eudistoma Olivaceum. J. Am. Chem. Soc. 1984, 106, 1524-1526. [CrossRef]

96. Hudson, J.B.; Saboune, H.; Abramowski, Z.; Towers, G.H.N.; Rinehart, K.L., Jr. The Photoactive Antimicrobial Properties of Eudistomins from the Caribbean Tunicate Eudistoma Olivaceum. Photochem. Photobiol. 1988, 47,377-381. [CrossRef] [PubMed]

97. Schupp, P.; Poehner, T.; Edrada, R.; Ebel, R.; Berg, A.; Wray, V.; Proksch, P. Eudistomins W and X, Two New $\alpha$-Carbolines from the Micronesian Tunicate Eudistoma Sp. J. Nat. Prod. 2003, 66, 272-275. [CrossRef]

98. Imperatore, C.; Cimino, P.; Cebrián-Torrejón, G.; Persico, M.; Aiello, A.; Senese, M.; Fattorusso, C.; Menna, M.; Doménech-Carbó, A. Insight into the Mechanism of Action of Marine Cytotoxic Thiazinoquinones. Mar. Drugs 2017, 15, 335. [CrossRef]

99. Casertano, M.; Menna, M.; Fattorusso, C.; Basilico, N.; Parapini, S.; Persico, M.; Imperatore, C. Antiplasmodial Activity of $p$-Substituted Benzyl Thiazinoquinone Derivatives and Their Potential against Parasitic Infections. Molecules 2020, 25, 1530. [CrossRef]

100. Gimmelli, R.; Persico, M.; Imperatore, C.; Saccoccia, F.; Guidi, A.; Casertano, M.; Luciano, P.; Pietrantoni, A.; Bertuccini, L.; Paladino, A.; et al. Thiazinoquinones as New Promising Multistage Schistosomicidal Compounds Impacting Schistosoma Mansoni and Egg Viability. ACS Infect. Dis. 2020, 6, 124-137. [CrossRef]

101. Imperatore, C.; Persico, M.; Senese, M.; Aiello, A.; Casertano, M.; Luciano, P.; Basilico, N.; Parapini, S.; Paladino, A.; Fattorusso, C.; et al. Exploring the Antimalarial Potential of the Methoxy-Thiazinoquinone Scaffold: Identification of a New Lead Candidate. Bioorganic Chem. 2019, 85, 240-252. [CrossRef]

102. Molinski, T.F. Marine Pyridoacridine Alkaloids: Structure, Synthesis, and Biological Chemistry. Chem. Rev. 1993, 93, 1825-1838. [CrossRef]

103. Ibrahim, S.R.M.; Mohamed, G.A. Marine Pyridoacridine Alkaloids: Biosynthesis and Biological Activities. Chem. Biodiversity 2016, 13, 37-47. [CrossRef] [PubMed]

104. Appleton, R.D.; Pearce, A.N.; Lambert, G.; Babcock, R.C.; Copp, B.R. Isodiplamine, Cystodytin K and Lissoclinidine: Novel Bioactive Alkaloids from the New Zealand Ascidian Lissoclinum Notti. Tetrahedron 2002, 58, 9779-9783. [CrossRef]

105. Kobayashi, J.; Cheng, J.; Walchli, M.R.; Nakamura, H.; Hirata, Y.; Sasaki, T.; Ohizumi, Y. Cystodytins A, B, and C, Novel Tetracyclic Aromatic Alkaloids with Potent Antineoplastic Activity from the Okinawan Tunicate Cystodytes Dellechiajei. J. Org. Chem. 1988, 53, 1800-1804. [CrossRef] 
106. Kobayashi, J.; Cheng, J.; Nakamura, H.; Ohizumi, Y.; Hirata, Y.; Sasaki, T.; Ohta, T.; Nozoe, S. Ascididemin, a novel pentacyclic aromatic alkaloid with potent antileukemic activity from the Okinawan tunicate Didemnum sp. Tetrahedron Lett. 1988, 29, 1177-1180. [CrossRef]

107. Bonnard, I.; Bontemps, N.; Lahmy, S.; Banaigs, B.; Combaut, G.; Francisco, C.; Colson, P.; Houssier, C.; Waring, M.J.; Bailly, C. Binding to DNA and Cytotoxic Evaluation of Ascididemin, the Major Alkaloid from the Mediterranean Ascidian Cystodytes Dellechiajei. AntiCancer Drug Des. 1995, 10, 333-346.

108. Schmitz, F.J.; De Guzman, F.S.; Hossain, M.B.; Van Der Helm, D. Cytotoxic Aromatic Alkaloids from the Ascidian Amphicarpa Meridiana and Leptoclinides Sp.: Meridine and 11-Hydroxyascididemin. J. Org. Chem. 1991, 56, 804-808. [CrossRef]

109. Delfourne, E.; Bontemps-Subielos, N.; Bastide, J. Structure Revision of the Marine Pentacyclic Aromatic Alkaloid: Cystodamine. Tetrahedron Lett. 2000, 41, 3863-3864. [CrossRef]

110. Kobayashi, J.; Tsuda, M.; Tanabe, A.; Ishibashi, M.; Cheng, J.F.; Yamamura, S.; Sasaki, T. Cystodytins D-I, New Cytotoxic Tetracyclic Aromatic Alkaloids from the Okinawan Marine Tunicate Cystodytes Dellechiajei. J. Nat. Prod. 1991, 54, 1634-1638. [CrossRef]

111. Torres, Y.R.; Bugni, T.S.; Berlinck, R.G.S.; Ireland, C.M.; Magalhães, A.; Ferreira, A.G.; Moreira, D.A.; Rocha, R. Sebastianines A and B, Novel Biologically Active Pyridoacridine Alkaloids from the Brazilian Ascidian Cystodytes Dellechiajei. J. Org. Chem. 2002, 67, 5429-5432. [CrossRef]

112. Bry, D.; Banaigs, B.; Long, C.; Bontemps, N. New Pyridoacridine Alkaloids from the Purple Morph of the Ascidian Cystodytes Dellechiajei. Tetrahedron Lett. 2011, 52, 3041-3044. [CrossRef]

113. Carroll, A.R.; Scheuer, P.J. Kuanoniamines A, B, C, and D: Pentacyclic Alkaloids from a Tunicate and Its Prosobranch Mollusk Predator Chelynotus Semperi. J. Org. Chem. 1990, 55, 4426-4431. [CrossRef]

114. Carroll, A.R.; Cooray, N.M.; Poiner, A.; Scheuer, P.J. A Second Shermilamine Alkaloid from a Tunicate Trididemnum Sp. J. Org. Chem. 1989, 54, 4231-4232. [CrossRef]

115. Eder, C.; Schupp, P.; Proksch, P.; Wray, V.; Steube, K.; Muller, C.E.; Frobenius, W.; Herderich, M.; van Soest, R.W.M. Bioactive Pyridoacridine Alkaloids from the Micronesian Sponge Oceanapia Sp. J. Nat. Prod. 1998, 61, 301-305. [CrossRef] [PubMed]

116. Copp, B.R.; Jompa, J.; Tahir, A.; Ireland, C.M. Styelsamines A-D: New Tetracyclic Pyridoacridine Alkaloids from the Indonesian Ascidian Eusynstyela Latericius. J. Org. Chem. 1998, 63, 8024-8026.

117. Zeng, C.; Ishibashi, M.; Matsumoto, K.; Nakaike, S.; Kobayashi, J. Two New Polycyclic Aromatic Alkaloids from the Okinawan Marine Sponge Biemna Sp. Tetrahedron 1993, 49, 8337-8342. [CrossRef]

118. Lopez-Legentil, S.; Turon, X.; Schupp, P. Chemical and Physical Defenses against Predators in Cystodytes (Ascidiacea). J. Exp. Mar. Biol. Ecol. 2006, 332, 27-36. [CrossRef]

119. Raub, M.F.; Cardellina, J.H., II. The Piclavines, Antimicrobial Indolizidines from the Tunicate Clavelina Picta. Tetrahedron Lett. 1992, 33, 2257-2260. [CrossRef]

120. Liu, J.; Li, X.-W.; Guo, Y.-W. Recent Advances in the Isolation, Synthesis and Biological Activity of Marine Guanidine Alkaloids. Mar. Drugs 2017, 15, 324. [CrossRef]

121. Sakai, R.; Higa, T. Tubastrine, a New Guanidinostyrene from the Coral Tubastrea Aurea. Chem. Lett. 1987, 127-128. [CrossRef]

122. Barenbrock, J.S.; Köck, M. Screening Enzyme-Inhibitory Activity in Several Ascidian Species from Orkney Islands Using Protein Tyrosine Kinase (PTK) Bioassay-Guided Fractionation. J. Biotechnol. 2005, 117, 225-232. [CrossRef]

123. Pearce, A.N.; Chia, E.W.; Berridge, M.W.; Maas, E.; Page, M.J.; Harper, J.L.; Webb, V.L.; Copp, B.R. Orthidines A-E, Tubastrine, 3,4-Dimethoxyphenethyl- $\beta$-Guanidine, and 1,14-Sperminedihomovanillamide: Potential Anti-Inflammatory Alkaloids Isolated from the New Zealand Ascidian Aplidium Orthium That Act as Inhibitors of Neutrophil Respiratory Burst. Tetrahedron 2008, 64, 5748-5755. [CrossRef]

124. Tadesse, M.; Tørfoss, V.; Strøm, M.B.; Hansen, E.; Andersen, J.H.; Stensvåg, K.; Haug, T. Isolation and Biological Activity of (E)-1-(4-Hydroxystyryl)Guanidine from the Sub-Arctic Ascidian, Dendrodoa Aggregata. Biochem. Syst. Ecol. 2010, 38, 827-829. [CrossRef]

125. Urban, S.; Capon, R.J.; Hooper, J.N.A. A New Alkaloid from an Australian Marine Sponge, Spongosorites Sp. Aust. J. Chem. 1994, 47, 2279-2282. [CrossRef]

126. Tadesse, M.; Strøm, M.B.; Svenson, J.; Jaspars, M.; Milne, B.F.; Tørfoss, V.; Andersen, J.H.; Hansen, E.; Stensvåg, K.; Haug, T. Synoxazolidinones A and B: Novel Bioactive Alkaloids from the Ascidian Synoicum Pulmonaria. Org. Lett. 2010, 12, 4752-4755. 
127. Tadesse, M.; Svenson, J.; Jaspars, M.; Strøm, M.B.; Abdelrahman, M.H.; Andersen, J.H.; Hansen, E.; Kristiansen, P.E.; Stensvåg, K.; Haug, T. Synoxazolidinone C; a Bicyclic Member of the Synoxazolidinone Family with Antibacterial and Anticancer Activities. Tetrahedron Lett. 2011, 52, 1804-1806. [CrossRef]

128. Miao, S.; Andersen, R.J. Rubrolides A-H, Metabolites of the Colonial Tunicate Ritterella Rubra. J. Org. Chem. 1991, 56, 6275-6280. [CrossRef]

129. Smith, C.J.; Hettich, R.L.; Jompa, J.; Tahir, A.; Buchanan, M.V.; Ireland, C.M. Cadiolides A and B, New Metabolites from an Ascidian of the Genus Botryllus. J. Org. Chem. 1998, 63, 4147-4150. [CrossRef]

130. Wang, W.; Kim, H.; Nam, S.J.; Rho, B.J.; Kang, H. Antibacterial Butenolides from the Korean Tunicate Pseudodistoma Antinboja. J. Nat. Prod. 2012, 75, 2049-2054. [CrossRef]

131. Won, T.H.; Jeon, J.; Kim, S.H.; Lee, S.H.; Rho, B.J.; Oh, D.C.; Oh, K.B.; Shin, J. Brominated Aromatic Furanones and Related Esters from the Ascidian Synoicum Sp. J. Nat. Prod. 2012, 75, 2055-2061. [CrossRef]

132. Sikorska, J.; Parker-Nance, S.; Davies-Coleman, M.T.; Vining, O.B.; Sikora, A.E.; McPhail, K.L. Antimicrobial Rubrolides from a South African Species of Synoicum Tunicate. J. Nat. Prod. 2012, 75, 1824-1827. [CrossRef]

133. Wang, W.; Kim, H.; Patil, R.S.; Giri, A.G.; Hwan Won, D.; Hahn, D.; Sung, Y.; Lee, J.; Choi, H.; Nam, S.-J.; et al. Cadiolides J-M, Antibacterial Polyphenyl Butenolides from the Korean Tunicate Pseudodistoma Antinboja. Bioorganic Med. Chem. Lett. 2016, 27, 574-577. [CrossRef]

134. Zhu, T.; Chen, Z.; Liu, P.; Wang, Y.; Xin, Z.; Zhu, W. New Rubrolides from the Marine-Derived Fungus Aspergillus Terreus OUCMDZ-1925. J. Antibiot. 2014, 67, 315-318. [CrossRef] [PubMed]

135. Bae, J.; Cho, E.; Park, J.S.; Won, T.H.; Seo, S.Y.; Oh, D.C.; Oh, K.B.; Shin, J. Isocadiolides A-H: Polybrominated Aromatics from a Synoicum Sp. Ascidian. J. Nat. Prod. 2020, 83, 429-437. [CrossRef] [PubMed]

136. Guo, Y.; Cai, S.; Gu, G.; Guo, Z.; Long, Z. Recent Progress in the Development of Sortase A Inhibitors as Novel Anti-Bacterial Virulence Agents. RSC Adv. 2015, 5, 49880-49889. [CrossRef]

137. Bhusal, R.P.; Bashiri, G.; Kwai, B.X.C.; Sperry, J.; Leung, I.K.H. Targeting Isocitrate Lyase for the Treatment of Latent Tuberculosis. Drug Discov. Today 2017, 22, 1008-1016. [CrossRef] [PubMed]

138. Das, S.; Lyla, P.S.; Khan, S.A. Marine Microbial Diversity and Ecology: Importance and Future Perspectives. Curr. Sci. 2006, 90, 1325-1335.

139. Dou, X.; Dong, B. Origins and Bioactivities of Natural Compounds Derived from Marine Ascidians and Their Symbionts. Mar. Drugs 2019, 17, 670. [CrossRef] [PubMed]

140. Donia, M.S.; Fricke, W.F.; Partensky, F.; Cox, J.; Elshahawi, S.I.; White, J.R.; Phillippy, A.M.; Schatz, M.C.; Piel, J.; Haygood, M.G.; et al. Complex Microbiome Underlying Secondary and Primary Metabolism in the Tunicate-Prochloron Symbiosis. Proc. Natl. Acad. Sci. USA 2011, 108, E1423-E1432. [CrossRef]

141. Rath, C.M.; Janto, B.; Earl, J.; Ahmed, A.; Hu, F.Z.; Hiller, L.; Dahlgren, M.; Kreft, R.; Yu, F.; Wolff, J.J.; et al. Metaomic Characterization of the Marine Invertebrate Microbial Consortium That Produces the Chemotherapeutic Natural Product ET-743. ACS Chem. Biol. 2011, 6, 1244-1256. [CrossRef]

142. Xu, Y.; Kersten, R.D.; Nam, S.G.; Lu, L.; Al-Suwailem, A.M.; Zheng, H.; Fenical, W.; Dorrestein, P.C.; Moore, B.S.; Qian, P.Y. Bacterial Biosynthesis and Maturation of the Didemnin Anti-Cancer Agents. J. Am. Chem. Soc. 2012, 134, 8625-8632. [CrossRef]

143. Tianero, M.D.; Kwan, J.C.; Wyche, T.P.; Presson, A.P.; Koch, M.; Barrows, L.R.; Bugni, T.S.; Schmidt, E.W. Species Specificity of Symbiosis and Secondary Metabolism in Ascidians. ISME J. 2015, 9, 615-628. [CrossRef] [PubMed]

144. Asolkar, R.N.; Kirkland, T.N.; Jensen, P.R.; Fenical, W. Arenimycin, an Antibiotic Effective against Rifampinand Methicillin-Resistant Staphylococcus Aureus from the Marine Actinomycete Salinispora Arenicola. J. Antibiot. 2010, 63, 37-39. [CrossRef] [PubMed]

145. He, H.; Ding, W.D.; Bernan, V.S.; Richardson, A.D.; Ireland, C.M.; Greenstein, M.; Ellestad, G.A.; Carter, G.T. Lomaiviticins A and B, Potent Antitumor Antibiotics from Micromonospora Lomaivitiensis. J. Am. Chem. Soc. 2001, 123, 5362-5363. [CrossRef] [PubMed]

146. Janso, J.E.; Haltli, B.A.; Eustáquio, A.S.; Kulowski, K.; Waldman, A.J.; Zha, L.; Nakamura, H.; Bernan, V.S.; He, H.; Carter, G.T.; et al. Discovery of the Lomaiviticin Biosynthetic Gene Cluster in Salinispora Pacifica. Tetrahedron 2014, 70, 4156-4164. [CrossRef]

147. Wyche, T.P.; Alvarenga, R.F.R.; Piotrowski, J.S.; Duster, M.N.; Warrack, S.R.; Cornilescu, G.; DeWolfe, T.J.; Hou, Y.; Braun, D.R.; Ellis, G.A.; et al. Chemical Genomics, Structure Elucidation, and in Vivo Studies of the Marine-Derived Anticlostridial Ecteinamycin. ACS Chem. Biol. 2017, 12, 2287-2295. [CrossRef] 
148. Fenical, W.; Jensen, P.R. Developing a New Resource for Drug Discovery: Marine Actinomycete Bacteria. Nat. Chem. Biol. 2006, 2, 666-673. [CrossRef]

149. Wyche, T.P.; Hou, Y.; Vazquez-Rivera, E.; Braun, D.; Bugni, T.S. Peptidolipins B-F, Antibacterial Lipopeptides from an Ascidian-Derived Nocardia Sp. J. Nat. Prod. 2012, 75, 735-740. [CrossRef]

150. Stefani, S.; Chung, D.R.; Lindsay, J.A.; Friedrich, A.W.; Kearns, A.M.; Westh, H.; MacKenzie, F.M. Meticillin-Resistant Staphylococcus Aureus (MRSA): Global Epidemiology and Harmonisation of Typing Methods. Int. J. Antimicrob. Agents 2012, 39, 273-282. [CrossRef]

151. De Kraker, M.E.A.; Wolkewitz, M.; Davey, P.G.; Koller, W.; Berger, J.; Nagler, J.; Icket, C.; Kalenic, S.; Horvatic, J.; Seifert, H.; et al. Clinical Impact of Antimicrobial Resistance in European Hospitals: Excess Mortality and Length of Hospital Stay Related to Methicillin-Resistant Staphylococcus Aureus Bloodstream Infections. Antimicrob. Agents Chemother. 2011, 55, 1598-1605. [CrossRef]

152. Ellis, G.A.; Wyche, T.P.; Fry, C.G.; Braun, D.R.; Bugni, T.S. Solwaric Acids A and B, Antibacterial Aromatic Acids from a Marine Solwaraspora Sp. Mar. Drugs 2014, 12, 1013-1022. [CrossRef]

153. Valliappan, K.; Sun, W.; Li, Z. Marine Actinobacteria Associated with Marine Organisms and Their Potentials in Producing Pharmaceutical Natural Products. Appl. Microbiol. Biotechnol. 2014, 98, 7365-7377. [CrossRef] [PubMed]

154. Sung, A.A.; Gromek, S.M.; Balunas, M.J. Upregulation and Identification of Antibiotic Activity of a Marine-Derived Streptomyces Sp. via Co-Cultures with Human Pathogens. Mar. Drugs 2017, 15, 250. [CrossRef] [PubMed]

155. Cuomo, V.; Palomba, I.; Perretti, A.; Guerriero, A.; D’Ambrosio, M.; Pietra, F. Antimicrobial Activities from Marine Fungi. J. Mar. Biotechnol. 1995, 2, 199-204.

156. Rahbaek, L.; Breinholt, J. Circumdatins D, E, and F: Further Fungal Benzodiazepine Analogues from Aspergillus Ochraceus J. Nat. Prod. 1999, 62, 904-905. [CrossRef]

157. Yurchenko, A.N.; Ivanets, E.V.; Smetanina, O.F.; Pivkin, M.V.; Dyshlovoi, S.A.; Amsberg, G.V.; Afiyatullov, S.S. Metabolites of the Marine Fungus Aspergillus Candidus KMM 4676 Associated with a Kuril Colonial Ascidian. Chem. Nat. Compd. 2017, 53, 747-749. [CrossRef]

158. Bugni, T.S.; Abbanat, D.; Bernan, V.S.; Maiese, W.M.; Greenstein, M.; Van Wagoner, R.M.; Ireland, C.M. Yanuthones: Novel Metabolites from a Marine Isolate of Aspergillus Niger. J. Org. Chem. 2000, 65, 7195-7200. [CrossRef]

159. Smetanina, O.F.; Kuznetsova, T.A.; Gerasimenko, A.V.; Kalinovsky, A.I.; Pivkin, M.V.; Dmitrenok, P.C.; Elyakov, G.B. Metabolites of the Marine Fungus Humicola Fuscoatra, KMM 4629. Russ. Chem. Bull. 2004, 36, 2643-2646. [CrossRef]

160. Tan, R.X.; Zou, W.X. Endophytes: A Rich Source of Functional Metabolites. Nat. Prod. Rep. 2001, 18, 448-459. [CrossRef]

161. Kobayashi, H.; Meguro, S.; Yoshimoto, T.; Namikoshi, M. Absolute Structure, Biosynthesis and Anti-Microtubule Activity of Phomopsidin, Isolated from a Marine-Derived Fungus Phomopsis Sp. Tetrahedron 2003, 59, 455-459. [CrossRef]

162. Proksh, P.; Edrada, R.A.; Ebel, R. Drugs From the Seas - Current Status and Microbiological Implications. Appl. Microbiol. Biotechnol. 2002, 59, 125-134.

163. Weindling, R. Experimental Consideration of the Mold Toxins of Gliocladium and Trichoderma. Phytopathology 1941, 31, 991-1003.

164. Garo, E.; Starks, C.M.; Jensen, P.R.; Fenical, W.; Lobkovsky, E.; Clardy, J. Trichodermamides A and B, Cytotoxic Modified Dipeptides from the Marine-Derived Fungus Trichoderma Virens. J. Nat. Prod. 2003, 66, 423-426.

165. Dittmann, E.; Fewer, D.P.; Neilan, B.A. Cyanobacterial Toxins: Biosynthetic Routes and Evolutionary Roots. FEMS Microbiol. Rev. 2013, 37, 23-43. [CrossRef] [PubMed]

166. Christophoridis, C.; Zervou, S.K.; Manolidi, K.; Katsiapi, M.; Moustaka-Gouni, M.; Kaloudis, T.; Triantis, T.M.; Hiskia, A. Occurrence and Diversity of Cyanotoxins in Greek Lakes. Sci. Rep. 2018, 8, 17877. [CrossRef] [PubMed]

167. Gkelis, S.; Panou, M.; Konstantinou, D.; Apostolidis, P.; Kasampali, A.; Papadimitriou, S.; Kati, D.; Di Lorenzo, G.M.; Ioakeim, S.; Zervou, S.-K.; et al. Diversity, Cyanotoxin Production, and Bioactivities of Cyanobacteria Isolated from Freshwaters of Greece. Toxins 2019, 11, 436. [CrossRef] 
168. Singh, R.; Parihar, P.; Singh, M.; Bajguz, A.; Kumar, J.; Singh, S.; Singh, V.P.; Prasad, S.M. Uncovering Potential Applications of Cyanobacteria and Algal Metabolites in Biology, Agriculture and Medicine: Current Status and Future Prospects. Front. Microbiol. 2017, 8, 515. [CrossRef]

169. Nunnery, J.K.; Mevers, E.; Gerwick, W.H. Biologically Active Secondary Metabolites from Marine Cyanobacteria. Curr. Opin. Biotechnol. 2010, 21, 787-793. [CrossRef]

170. Socha, A.M.; Garcia, D.; Sheffer, R.; Rowley, D.C. Antibiotic Bisanthraquinones Produced by a Streptomycete Isolated from a Cyanobacterium Associated with Ecteinascidia Turbinata. J. Nat. Prod. 2006, 69, 1070-1073. [CrossRef]

(C) 2020 by the authors. Licensee MDPI, Basel, Switzerland. This article is an open access article distributed under the terms and conditions of the Creative Commons Attribution (CC BY) license (http://creativecommons.org/licenses/by/4.0/). 